Article

\title{
Enrichment Mechanisms of Gallium and Indium in No. 9 Coals in Anjialing Mine, Ningwu Coalfield, North China, with a Preliminary Discussion on Their Potential Health Risks
}

\author{
Minmin Zhang ${ }^{1,2} \mathbb{D}$, Huidi Hao ${ }^{3}$, Lei Tian ${ }^{4}$, Jinxi Wang ${ }^{2}$, Yanheng Li $^{2}$ and Yuzhuang Sun ${ }^{2,3, *}$ \\ 1 School of Water Conservancy and Hydroelectric Power, Hebei University of Engineering, \\ Handan 056038, China; HUEZhangMM@126.com \\ 2 Key Laboratory of Resource Exploration Research of Hebei Province, Hebei University of Engineering, \\ Handan 056038, China; wangjinxi@hebeu.edu.cn (J.W.); wsaluo@163.com (Y.L.) \\ 3 School of Earth Science and Engineering, Hebei University of Engineering, Handan 056038, China; \\ 17853463993@163.com \\ 4 China Coal Geology Group Co. Ltd., Beijing 100040, China; tldyx-4@163.com \\ * Correspondence: syz@hebeu.edu.cn
}

check for updates

Citation: Zhang, M.; Hao, H.; Tian, L.; Wang, J.; Li, Y.; Sun, Y. Enrichment Mechanisms of Gallium and Indium in No. 9 Coals in Anjialing Mine, Ningwu Coalfield, North China, with a Preliminary Discussion on Their Potential Health Risks. Minerals 2021, 11, 64. https://doi.org/10.3390/ $\min 11010064$

Received: 28 November 2020 Accepted: 7 January 2021 Published: 11 January 2021

Publisher's Note: MDPI stays neutral with regard to jurisdictional clai$\mathrm{ms}$ in published maps and institutional affiliations.

Copyright: $\odot 2021$ by the authors. Licensee MDPI, Basel, Switzerland. This article is an open access article distributed under the terms and conditions of the Creative Commons Attribution (CC BY) license (https:// creativecommons.org/licenses/by/ $4.0 /)$.
Abstract: To provide a comprehensive insight into the enrichment mechanism of gallium and indium in No. 9 coals, eighteen samples were collected from Anjialing mine, Ningwu Coalfield, Shanxi Province for coal petrological, mineralogical and geochemical analyses. The results suggested that Ga and In enrichment mainly hosted in the top horizons, with average concentration coefficients of 8.99 and 2.73 respectively, compared with the rest of horizons (2.46 for Ga and 1.69 for In). Source apportionment indicated that $\mathrm{Ga}$ and In were mainly derived from bauxite of Benxi Formation in Yinshan Oldland, while In could originate from felsic magmatic rocks in Yinshan Oldland as well. In addition, weak oxidation condition, medium to intensive weathering, transgression and input of terrestrial higher plants had positive effects on Ga and In enrichment. With the rapid expansion of emerging electronics manufacturing, Ga and In, of which potential risks on human health were neglected previously, were recently considered as hazardous elements. Therefore, this paper also discussed the potential pathways that these elements threatened human health. We suggested that potential risks on environment and human health caused by Ga and In enrichment in coals and coal-related products should be taken into account besides their economic value.

Keywords: gallium; indium; enrichment mechanism; potential health risks; Ningwu Coalfield

\section{Introduction}

As one of major non-regeneration energy, coal has been performing as an important constituent part of the world's energy structure for a longtime [1]. In the past decades, coal production and consumption around the world have surged more than $150 \%$, and it was estimated that coal will account for more than $24 \%$ in the proportion of primary energy by 2035 [2]. Coal remains as a valuable resource that is still used for both industrial and domestic purposes in many countries globally [3-5]. Besides being fossil fuel for energy supply, coal with some rare and critical trace elements of higher concentration is also considered as economic even strategic resource. These highly enriched elements, including Ag, Al, Au, Ga, Ge, In, Li, Mg, Nb, Sc, Se, U, V, and REE+Y [6-9], will be utilizable by-products if appropriate recovery procedures are conducted during coal cleaning and treatment of combustion residues. For examples, high concentration of Ge was found in coal from Lincang, Yimin, Jungar, and Wulantuga, China [10-13], and Russian Far East $[14,15]$. High concentration of $\mathrm{Li}$ was reported in coal from Junger Coalfield and Ningwu Coalfield [11,16-21]. Meanwhile, a number of techniques have been developed for recycling these valuable elements, especially from coal fly ash (CFA). Torralvo et al. [22] employed ion-exchange procedures to recover Ge from CFA. Fang and Gesser [23] explored 
technological process of Ga recovery from CFA, involving acid leaching, foam extraction and further purification. Zhao et al. [24] invented a stepwise separation method using acidic extractant for selective recovery of Ga from leachate of CFA.

Although elements hosted in coal can facilitate comprehensive utilization of coal resource themselves by development of recovery technologies, however, they also cause serious environmental problems that may threaten human health ultimately due to their potential toxicity once they reach a certain environmental level. A quantity of coal-related cases have been reported around the world, some of which are confirmed that the adverse influences are caused by anomalously enriched elements in coal. It has been reported that harmful elements could be released from coal and coal-related products in the processes of natural weathering and leaching [25] and combustion [26,27], both of which can lead exposure population to chronic poisoning, containing arsenosis [28,29], fluorosis [30-33], selenosis [34-36], and etc. Therefore, more considerations should be taken in the processes of coal exploitation and utilization in order to benefit from both economic and environmental aspects.

There have been a large number of studies conducted on coal in Shanxi Province, China because not only its huge coal reserves and yield ranked higher among provinces (in 2019) [37] but also several elements within it are significantly enriched, such as Li, Ga and Al [17,20,21,38-41]. Nonetheless, most of these studies were based on view of associated resources, while few was focused on potential of jeopardizing human health [42]. In some cases, understanding on pernicousness from specific elements is gradually improved with the development of emerging industrial and surge usage of the elements. It is noteworthy that Ga and In, which show enrichment in some coal seams from Pingshuo Mine District, Ningwu Coalfield, Shanxi Province, have been recognized as potential harmful elements in recent years because of increased industrial use in photovoltaics and integrated circuit $[43,44]$ which may translate into increased environmental concentrations and high exposure level to human [45]. Because of the capacity of providing efficient optical transitions and high electron mobility, Ga and its compounds are widely applied in integrated circuits, semiconductors and optoelectronic devices, and also used in metal alloys, nuclear weapons, and medication [46-48]. Indium and its compounds are mainly used in light-emitting diodes, liquid-crystal display, batteries, and thin coating on plasma display and touch panels $[49,50]$. Gallium and In are typical dispersed chalcophilic metallic elements with low concentrations in the Earth's crust $(15-19 \mu \mathrm{g} / \mathrm{g}$ and $0.05-0.07 \mu \mathrm{g} / \mathrm{g}$, respectively) [51,52]. However, some anthropogenic activities can render abnormal high environmental concentration level on the local scale, which may lead to acute and chronic exposure to $\mathrm{Ga}$, In and their compounds [53], and ultimately result in diseases. It was reported that gallium sulfate can suppress the heme synthesis [54], gallium could damage testicular tissue via chronic exposure pathway [48], and immunosuppression and pulmonary lesions can be caused by gallium arsenide in which gallium could also play an important role on the effects $[55,56]$. Since In is mainly produced and used in the form of indium-tin oxide (ITO), numerous cases occurred in electronic products manufacturing involving In-contained materials $[57,58]$. Inhaled ITO particles trend to accumulate in the deep parts of lung then induce pulmonary alveolar proteinosis, fibrosis and emphysema, even malignant lung tumors [59-61].

Our previous study found that several trace elements were enriched in No. 9 coals in Anjialing surface mine in Pingshuo Mine District, especially Li and Ga that can reach the economically valuable level [62]. However, potential negative influences caused by releasing of Ga and In from Ga- and In-enriched coal in Pingshuo Mine District in the processes of excavation, transportation, inappropriate disposal and combustion may contaminate the ecological environment, and finally threaten human health. Moreover, there is deficiency in regard of detailed study on enrichment mechanism and source apportionment of these selected elements. Thus, eighteen coal samples of No. 9 Coals from Anjialing surface mine in Pingshuo Mine District, Ningwu Coalfield, Shanxi Province were employed to enhance geochemical and coal petrological evidences of enrichment characteristics and provenance 
of Ga and In. After a preliminary discussion, we also tried to emphasize the potential hazard induced by these two elements in order to provoke sufficient concern about the elements of which potential toxicity was neglected previously.

\section{Geological Setting}

Anjialing surface mine is located in Pingshuo Mine District of northern Ningwu Coalfield, Shanxi Province, North China (Figure 1a). The mine covers an area of $28.88 \mathrm{~km}^{2}$ and displays a decreasing trend in elevation from northwest to southeast. Tectonically, the mine situates in the northwest part of Ningwu syncline basin. Occurrences of coal-bearing strata in the basin, including extension direction, dip angle and dipping direction, are controlled by the syncline. There is seldom fault and no magmatic activity occurred in the area. Stratigraphically, the terrane is comprised of Ordovician, Carboniferous, Permian, Neogene, and Quaternary from bottom to top. Benxi, Taiyuan, and Shanxi Formation of Pennsylvanian to Cisuralian are mainly composed of sandstone, mudstone and shale intercalated by limestone and coal. There are a total of nine coal seams, of which Nos. 4, 9, and 11 in Taiyuan Formation are major minable seams with average thicknesses of $10.38 \mathrm{~m}$, $16.26 \mathrm{~m}$, and $4.1 \mathrm{~m}$ in Anjialing surface mine, respectively. Previous studies indicated a delta plain environment during coal-forming period of Nos. 9 and 11 coal seams, which was suffered from multi-stage transgressions [62-65]. Moreover, terrestrial detritus from Yinshan Oldland, together with input materials from seawater, significantly influenced the petrographical, mineralogical, and geochemical characteristics of the coal $[20,63,65]$.

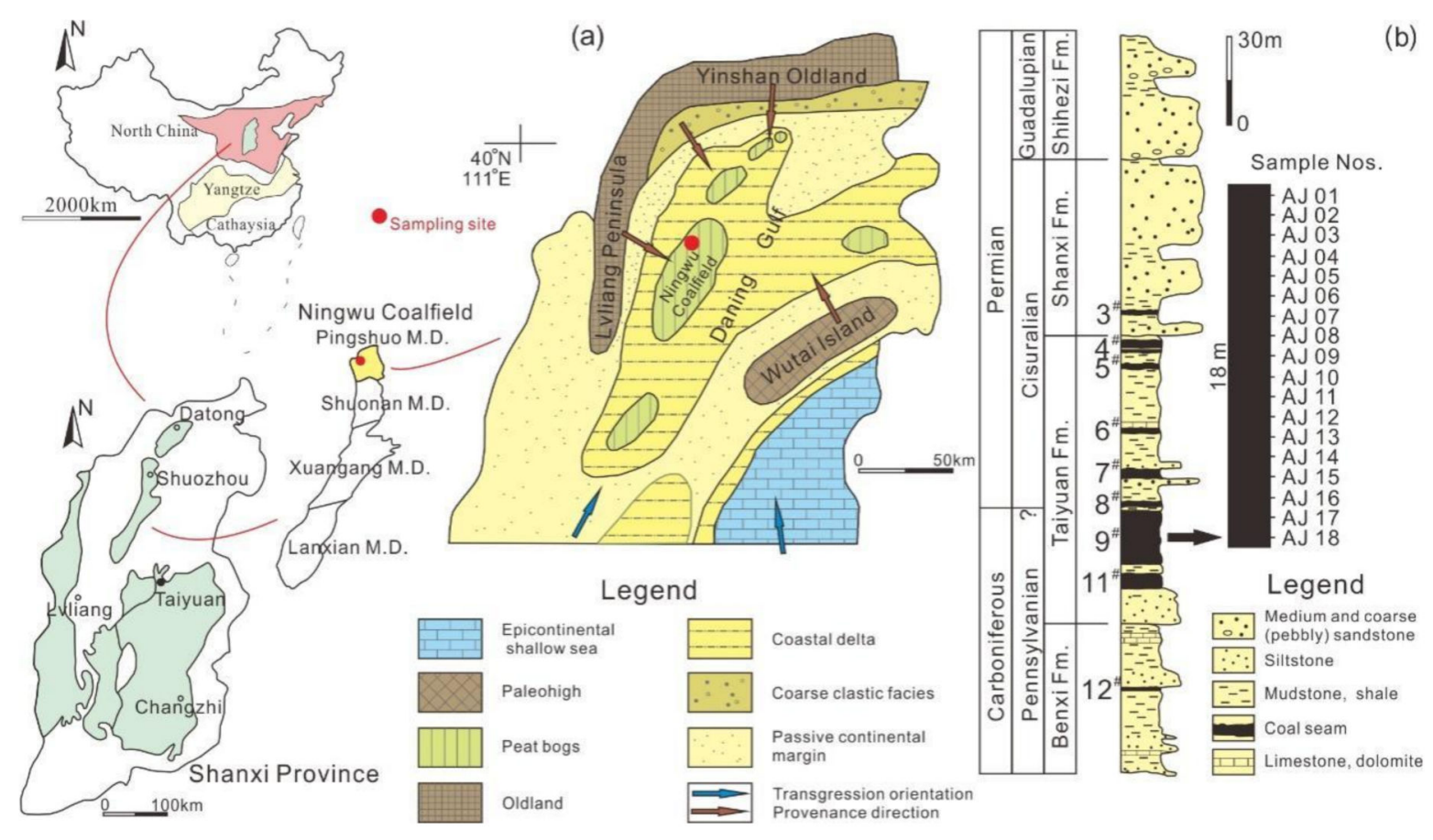

Figure 1. (a) Location of sampling site in Anjialing surface mine in Pingshuo Mine District and paleogeographic map of Ningwu Coalfield (modified from Zhuang et al. [65]). (b) Lithological column of Carboniferous (Pennsylvanian) to Permian (Guadalupian) in Anjialing surface mine and sampling horizons in No. 9 coals.

\section{Material and Analytical Methods}

Eighteen coal samples, numbered in order as AJ01 to AJ18 from top to bottom, were collected every $1 \mathrm{~m}$ thickness from No. 9 coals in Anjialing surface mine (Figure 1b). The sampling campaign was conducted following Chinese standard GB/T 482-1985 [66]. All samples were sealed by plastic bags for minimizing contamination and oxidation after collection, then were transported to laboratory for further analysis. Each sample was di- 
vided into two sub-samples, one of which was pulverized in the agate mortar and passed through 200-mesh sieve prior to proximate, geochemical, petrological and mineralogical analyses. The procedures of measuring ash yield, moisture, volatile matter, total sulfur and gross calorific value complied with the standard methods of ASTM Standard D317411 [67], ASTM Standard D3173-11 [68], ASTM Standard D3175-11 [69], ASTM Standard D3177-02 [70], and ASTM Standard D5865-13 [71], respectively. The random vitrinite reflectance $\left(R_{r}\right)$ was determined by Leica DM2500P (Leica Microsystems, Wetzlar, Germany) reflected-light microscope equipped with halogen lamp and spectrophotometry (TIDAS MSP 400, J\&M Analytik AG, Essingen, Germany) according to ASTM D2798-11a [72]. The concentrations of major element oxides, including $\mathrm{SiO}_{2}, \mathrm{Fe}_{2} \mathrm{O}_{3}, \mathrm{Al}_{2} \mathrm{O}_{3}, \mathrm{CaO}$, and $\mathrm{MgO}$ in high-temperature ash $\left(815^{\circ} \mathrm{C}\right)$, were measured by $\mathrm{X}$-ray fluorescence spectrometry (XRF, ARL Perform'X, Thermo Fisher Scientific, Waltham, MA, USA). The concentrations of trace elements, including $\mathrm{Li}$, Be, Sc, V, Cr, Co, Ni, Cu, Zn, Ga, Rb, Y, Zr, Nb, Mo, Cd, In, Sb, Cs, Ba, $\mathrm{Hf}, \mathrm{Ta}, \mathrm{W}, \mathrm{Tl}, \mathrm{Pb}, \mathrm{Bi}$, Th, $\mathrm{U}$, and REE, were measured by inductively coupled plasma mass spectrometry (ICP-MS, ElementI, Finnigan MAT, San Jose, CA, USA). The data of trace element and REE concentrations had been employed by Wang et al. [62] for analysis of their characteristics. Another sub-sample was selected for Soxhlet extraction (experimental procedure was provided by Yang and Zhao [73]), then was determined by a Hewlett-Packard model 6890 gas chromatography coupled with a Hewlett-Packard model 5973 quadrupole Mass Spectrometric Detection (MSD) (GS-MS, Agilent Technologies, Santa Clara, CA, USA) to analyze organic geochemical characteristics, i.e., distribution patterns of concentrations of saturated hydrocarbons and aromatic hydrocarbons. Detailed analytical procedures are provided in Supplementary Material (Section S1). Standard materials, blank samples and parallel samples were employed in experiment process for verification on precision of measurement results. Regarding the parameters selected in this paper, concentration coefficient $(\mathrm{CC}), \delta \mathrm{Ce}, \delta \mathrm{Eu}$, and $(\mathrm{La} / \mathrm{Yb})_{\mathrm{N}}$ were calculated for quantitative evaluation of enrichment degree, anomaly of $\mathrm{Ce}$ and $\mathrm{Eu}$, and fractionation between LREE and HREE, respectively. Their calculation formulas are provided in Supplementary Material (Section S2). Hierarchical cluster analysis (HCA) was conducted by IBM SPSS Statistics version 23.0.

\section{Results and Discussions}

\subsection{General Characteristics of No. 9 Coals}

The results of proximate analysis and gross calorific values were listed in Table S1. The moisture on air-dry basis ranged from $1.09 \%$ to $5.54 \%$, and averaged at $2.46 \%$. The ash yield on dry basis varied between $13.30 \%$ and $39.08 \%$, with an average of $22.95 \%$. The volatile matter on dry and ash-free basis changed from $35.54 \%$ to $49.67 \%$, and averaged at $41.15 \%$. The total sulfur content on dry basis was between $0.41 \%$ and $4.71 \%$, with an average of $2.17 \%$. The gross calorific value on air-dry basis changed from $21.35 \mathrm{MJ} / \mathrm{kg}$ to $29.60 \mathrm{MJ} / \mathrm{kg}$, and averaged at $24.60 \mathrm{MJ} / \mathrm{kg}$. This indicated that No. 9 coals from Anjialing surface mine can be classified as medium-ash coal [74], medium-high-sulfur coal [75], and also high volatile $C$ bituminous coal [76].

\subsection{Coal Petrological Characteristics}

Maceral composition of No. 9 coals in Anjialing surface mine was listed in Table 1. The vitrinite was dominated by collodetrinite and, in a decreasing order of content, vitrodetrinite, collotelinite and telinite. Generally, amorphous collodetrinite preformed as cement of maceral and mineral components. Banding and lenticular collotelinite presented in vitrinite group. Telinite with cell structure was filled with kaolinite, calcite, quartz and other macerals. The average of random vitrinite reflectance $\left(R_{r}\right)$ was $0.59 \%$. The inertinite was dominated by fusinite and semifusinite, only a small proportion of funginite, inertodetrinite, macrinite and micrinite can be distinguished. The cell structures of fusinite and semifusinite showed fracture, deformation, and swelling. The liptinite was dominated by liptodetrinite, cutinite and sporinite. There was also a very small amount of exsudatinite and suberinite in the liptinite group. 
Table 1. Maceral composition of No. 9 coal seam.

\begin{tabular}{|c|c|c|c|c|c|c|c|c|c|c|c|c|c|c|c|c|c|}
\hline \multirow{2}{*}{$\begin{array}{c}\text { Sample } \\
\text { Nos. }\end{array}$} & \multicolumn{5}{|c|}{ Vitrinite (vol\%, mmf) } & \multicolumn{7}{|c|}{ Inertinite (vol $\%, \mathrm{mmf})$} & \multicolumn{4}{|c|}{ Liptinite (vol\%, mmf) } & \multirow{2}{*}{$\mathbf{R}_{\mathbf{r}}(\%)$} \\
\hline & TL & CT & $\mathrm{CD}$ & VD & $\mathrm{T}-\mathrm{V}$ & SF & FUS & MA & MI & FUN & ID & T-I & SP & $\mathrm{CU}$ & LD & T-L & \\
\hline AJ01 & - & 0.5 & 19.5 & 6.0 & 26.0 & 28.9 & 10.7 & - & 1.6 & - & 19.5 & 60.7 & 1.3 & 1.8 & 10.2 & 13.3 & 0.63 \\
\hline AJ02 & - & 3.4 & 55.0 & 1.0 & 59.4 & 17.8 & 6.7 & - & 0.6 & - & 4.4 & 29.5 & 2.6 & 1.8 & 6.7 & 11.1 & 0.64 \\
\hline AJ03 & 1.7 & 11.6 & 34.4 & 7.4 & 55.1 & 13.1 & 6.8 & - & - & - & 8.2 & 28.1 & 2.6 & 8.8 & 5.4 & 16.8 & 0.60 \\
\hline AJ04 & 0.9 & 1.5 & 31.4 & 3.8 & 37.6 & 21.7 & 5.6 & 1.5 & 0.9 & - & 15.9 & 45.6 & 2.1 & 6.2 & 8.5 & 16.8 & 0.55 \\
\hline AJ05 & 2.7 & 16.2 & 44.9 & 4.8 & 68.6 & 8.4 & 8.9 & 0.7 & - & 0.2 & 3.0 & 21.2 & 2.5 & 3.4 & 4.3 & 10.2 & 0.63 \\
\hline AJ06 & - & 3.7 & 53.4 & 10.8 & 67.9 & 7.7 & 9.6 & - & 0.8 & - & 4.2 & 22.3 & 4.0 & 2.1 & 3.7 & 9.8 & 0.64 \\
\hline AJ07 & 1.2 & 7.6 & 40.1 & 7.4 & 56.3 & 23.4 & 7.4 & - & 1.0 & - & 3.8 & 35.6 & 2.6 & 2.6 & 2.9 & 8.1 & 0.71 \\
\hline AJ08 & 4.0 & 11.9 & 7.1 & 5.5 & 28.5 & 37.2 & 7.7 & 1.8 & - & - & 13.5 & 60.2 & 1.3 & 4.5 & 5.5 & 11.3 & 0.70 \\
\hline AJ09 & 0.2 & 0.4 & 39.7 & 1.1 & 41.4 & 31.2 & 12.2 & - & 0.2 & 0.4 & 8.1 & 52.1 & 1.3 & 2.8 & 2.4 & 6.5 & 0.53 \\
\hline AJ10 & - & 6.3 & 56.9 & 7.8 & 71.0 & 13.6 & 3.2 & - & - & - & 4.9 & 21.7 & 1.2 & 3.2 & 2.9 & 7.3 & 0.69 \\
\hline AJ11 & 0.5 & 3.5 & 29.3 & 5.5 & 38.8 & 32.0 & 19.4 & 0.2 & - & - & 2.5 & 54.1 & 2.5 & 2.5 & 2.1 & 7.1 & 0.57 \\
\hline AJ12 & - & 2.7 & 62.2 & 4.7 & 69.6 & 13.7 & 6.1 & 0.2 & - & 0.1 & 2.9 & 23.0 & 1.6 & 2.9 & 2.9 & 7.4 & 0.51 \\
\hline AJ13 & 2.4 & 1.9 & 27.5 & 2.1 & 33.9 & 36.4 & 12.0 & 0.5 & 0.3 & 0.2 & 6.1 & 55.5 & 2.4 & 4.5 & 3.7 & 10.6 & 0.49 \\
\hline AJ14 & 0.6 & 2.6 & 59.3 & 3.9 & 66.4 & 17.1 & 4.5 & - & 0.6 & 0.4 & 3.6 & 26.2 & 0.6 & 3.2 & 3.6 & 7.4 & 0.50 \\
\hline AJ15 & - & 1.8 & 38.1 & 5.6 & 45.5 & 25.9 & 7.6 & - & 1.0 & - & 4.6 & 39.1 & 4.8 & 5.3 & 5.3 & 15.4 & 0.53 \\
\hline AJ16 & 2.8 & 4.1 & 45.4 & 3.8 & 56.1 & 21.3 & 7.4 & - & 0.5 & 0.3 & 4.8 & 34.3 & 1.5 & 6.3 & 1.8 & 9.6 & 0.61 \\
\hline
\end{tabular}

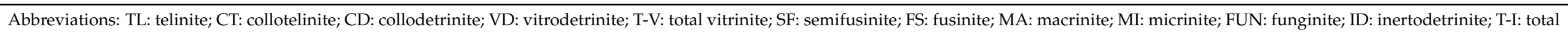

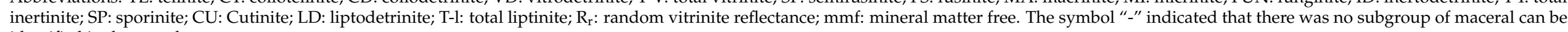
identified in the sample. 


\subsection{Geochemical Characteristics}

\subsubsection{Major Element Oxides}

As shown in Table $\mathrm{S} 2, \mathrm{SiO}_{2}$ and $\mathrm{Al}_{2} \mathrm{O}_{3}$ were dominant constituents of major oxides in No. 9 coals, and the latter (averaged at 9.49) was higher than the former (8.49). Average of $\mathrm{Al}_{2} \mathrm{O}_{3}$ concentrations was nearly twice as the average value in the Chinese coal (5.98) [77], while that of $\mathrm{SiO}_{2}$ was approximate to the Chinese coal (8.47). Similarly, $\mathrm{CaO}$ (1.48) and $\mathrm{MgO}(0.16)$ in No. 9 coals were also close to the Chinese coal (1.23 and 0.22 , respectively). The ratios of $\mathrm{SiO}_{2} / \mathrm{Al}_{2} \mathrm{O}_{3}$ ranged between 0.34 and 1.32, with an average of 0.90 which was less than the Chinese coals (1.42). Compared with theoretical ratio of kaolinite (1.18), the lower average in No. 9 coals indicated that surplus Al hosted in minerals such as boehmite, possibly because strong input of weathering products from provenance elevated $\mathrm{Al}$ concentration in coal. Moreover, there was seldom quartz presented in No. 9 coals. $\mathrm{Fe}_{2} \mathrm{O}_{3}$ (0.82) in No. 9 coals was far below the Chinese coal (4.85). Pyrite is common Fe-containing mineral in coal, and it trends to enriched under reductive condition in sedimentary environment. Thus, the lower content of Fe could be caused by oxidative condition during peat accumulation.

\subsubsection{Trace Elements}

The concentrations of trace element in No. 9 coals were listed in Table S3. In comparison with the Chinese coal, Li, Ga, Sr, Zr, and Th in No. 9 coal showed higher concentrations while $\mathrm{Co}, \mathrm{Ni}, \mathrm{Cs}$, and $\mathrm{Tl}$ showed lower concentrations. The rest of trace elements had a proximate order of magnitude with the Chinese coal (Figure 2a). Previous studies corroborated that coal seams of Pennsylvanian and Early Permian in age from Shanxi Province and Inner Mongolia generally enriched in $\mathrm{Li}, \mathrm{Ga}, \mathrm{Sr}, \mathrm{Ba}, \mathrm{Zr}, \mathrm{Hf}$, and Th within different levels $[3,19-21,62,65,78]$. Concentration coefficient (CC) is an effective index to elucidate enrichment signature of elements in coal. As recommended by Dai et al. [79], enrichment levels evaluated by CC can be divided into six intervals, which are unusually enriched (CC > 100), significantly enriched (10-100), enriched (5-10), slightly enriched (2-5), close to average $(0.5-2)$, and depleted $(\mathrm{CC}<0.5)$. In No. 9 coals, $\mathrm{Li}$ was the most enriched trace element with average CC of 11.71, and followed by $\mathrm{Zr}(6.49)$, Hf (5.34), Sr (4.78), Ga (4.28), $\mathrm{Nb}$ (3.77), Th (3.19), Ta (2.79), Pb (2.75), Zn (2.02), In (1.98), Y (1.95), Cr (1.55), Sc (1.51), V (1.31), Cu (1.17), U (1.09), Mo (0.94), W (0.92), Sb (0.89), Be (0.72), Ba (0.57), Cd (0.49), Cs (0.48), Bi (0.43), Rb (0.41), Ni (0.38), Co (0.38), and Tl (0.15) (Figure 2b). In terms of $\mathrm{Ga}$ and In, an evident differentiation of enrichment on vertical scale of coal seams can be distinguished, although their variations were not completely synchronous. Overall, CC values of Ga varied from 0.60 to14.28 (averaged at 4.28), and those of In varied from 0.39 to 5.48 (averaged at 1.98). Standard deviation values of $\mathrm{Ga}$ and In were 3.462 and 1.280 respectively, indicating that Ga showed higher degree of dispersion in CC values than In. Table 2 revealed that Ga and In mainly occurred in upper horizons of No. 9 coals (AJ01-AJ05), with average CC values of 8.99 and 2.73 respectively, compared with middle and lower horizons (AJ06-AJ18) of which average CC values were 2.46 and 1.69 respectively. An exception occurred in the bottom of coal seam (AJ18) in which CC value of Ga (5.47) indicated an enriched degree. Concentrations of REE in No. 9 coals were listed in Table S4. Distribution patterns of REE in No. 9 coals were similar to that in the Chinese coal, showing as steep curves with rightward inclination as well as significantly negative Eu anomaly (averaged at 0.57 ) and slightly negative Ce anomaly (averaged at 0.89). Average CC values of REE, LREE, and HREE were 2.02, 2.11, and 1.44 respectively, indicating LREE in No. 9 coal was slightly enriched while HREE was similar to the average of the World hard coal. 
Table 2. Parameters for enrichment classification, identification of deposition condition and source apportionment of Ga and In in No. 9 coals.

\begin{tabular}{|c|c|c|c|c|c|c|c|c|c|c|c|c|c|}
\hline \multirow{2}{*}{ Sample Nos. } & \multicolumn{2}{|c|}{$\mathrm{CC}$} & \multicolumn{2}{|c|}{ Paleo-Salinity } & \multirow{2}{*}{$\begin{array}{c}\text { WI } \\
\text { Th/U }\end{array}$} & \multicolumn{4}{|c|}{ Redox Condition and Sedimentary Environment } & \multicolumn{4}{|c|}{ Source Apportionment } \\
\hline & Ga & In & $\mathrm{Sr}^{*}$ & Th * & & $\delta \mathrm{Ce}$ & $\mathrm{Pr} / \mathrm{Ph}$ & $\mathrm{Pr} / \mathbf{n C}_{17}$ & $\mathrm{Ph} / \mathrm{nC}_{18}$ & $\mathbf{H f}^{*}$ & $\mathrm{La} / \mathrm{Th}$ & $\mathrm{La} / \mathrm{Sc}$ & $\mathrm{Co} / \mathrm{Th}$ \\
\hline AJ01 & 5.40 & 3.26 & 111 & 21.7 & 4.41 & 0.85 & 2.63 & 1.82 & 0.64 & 11.70 & 3.64 & 4.36 & 0.31 \\
\hline AJ02 & 10.19 & 0.68 & 1792 & 2.91 & 0.50 & 0.78 & 4.81 & 3.87 & 0.91 & 1.84 & 37.11 & 17.12 & 1.66 \\
\hline AJ03 & 7.91 & 3.35 & 97.2 & 15.5 & 7.67 & 0.86 & - & - & - & 13.10 & 1.14 & 2.30 & 0.12 \\
\hline AJ04 & 7.17 & 5.48 & 4669 & 34.7 & 5.37 & 0.74 & 1.58 & 0.81 & 0.60 & 12.90 & 3.29 & 11.92 & 0.05 \\
\hline AJ05 & 14.28 & 0.87 & 635 & 3.36 & 8.20 & 1.05 & - & - & - & 3.92 & 1.65 & 1.80 & 0.66 \\
\hline AJ06 & 2.66 & 1.58 & 133 & 3.74 & 4.29 & 0.84 & - & - & - & 4.46 & 2.37 & 4.00 & 0.27 \\
\hline AJ07 & 2.05 & 1.58 & 257 & 8.91 & 3.93 & 0.88 & - & - & - & 4.57 & 3.60 & 5.10 & 0.29 \\
\hline AJ08 & 2.03 & 4.03 & 207 & 26.8 & 6.91 & 0.92 & 1.78 & 0.99 & 0.62 & 8.95 & 0.91 & 2.08 & 0.02 \\
\hline AJ09 & 3.43 & 1.90 & 56.3 & 3.11 & 1.08 & 0.97 & - & - & - & 5.04 & 2.10 & 1.30 & 0.31 \\
\hline AJ10 & 2.21 & 2.13 & 79.3 & 5.68 & 3.12 & 0.84 & 3.43 & 1.84 & 0.54 & 3.65 & 1.11 & 1.99 & 0.11 \\
\hline AJ11 & 1.88 & 0.81 & 68.1 & 3.91 & 4.09 & 0.78 & - & - & - & 2.51 & 0.46 & 0.98 & 0.16 \\
\hline AJ12 & 2.02 & 1.03 & 162 & 2.58 & 1.91 & 1.01 & - & - & - & 1.80 & 1.88 & 2.32 & 0.39 \\
\hline AJ13 & 1.74 & 1.16 & 257 & 9.09 & 3.79 & 0.89 & - & - & - & 5.03 & 1.57 & 3.09 & 0.05 \\
\hline AJ14 & 2.52 & 1.29 & 114 & 8.75 & 4.63 & 1.06 & - & - & - & 4.24 & 0.25 & 0.66 & 0.09 \\
\hline AJ15 & 2.57 & 2.35 & 165 & 12.2 & 3.63 & 0.90 & 2.68 & 1.71 & 0.52 & 13.30 & 0.72 & 1.73 & 0.08 \\
\hline AJ16 & 2.84 & 2.03 & 360 & 9.47 & 3.36 & 0.94 & - & - & - & 4.39 & 4.38 & 8.56 & 0.13 \\
\hline AJ17 & 0.60 & 0.39 & 270 & 1.53 & 3.60 & 0.87 & 3.40 & 2.47 & 0.57 & 1.38 & 10.26 & 11.29 & 0.60 \\
\hline Avg. & 4.28 & 1.98 & 525.9 & 10.52 & 4.26 & 0.89 & 2.76 & 1.90 & 0.66 & 6.41 & 4.37 & 4.68 & 0.31 \\
\hline
\end{tabular}

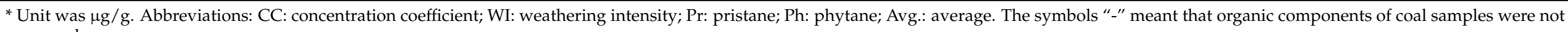
measured. 


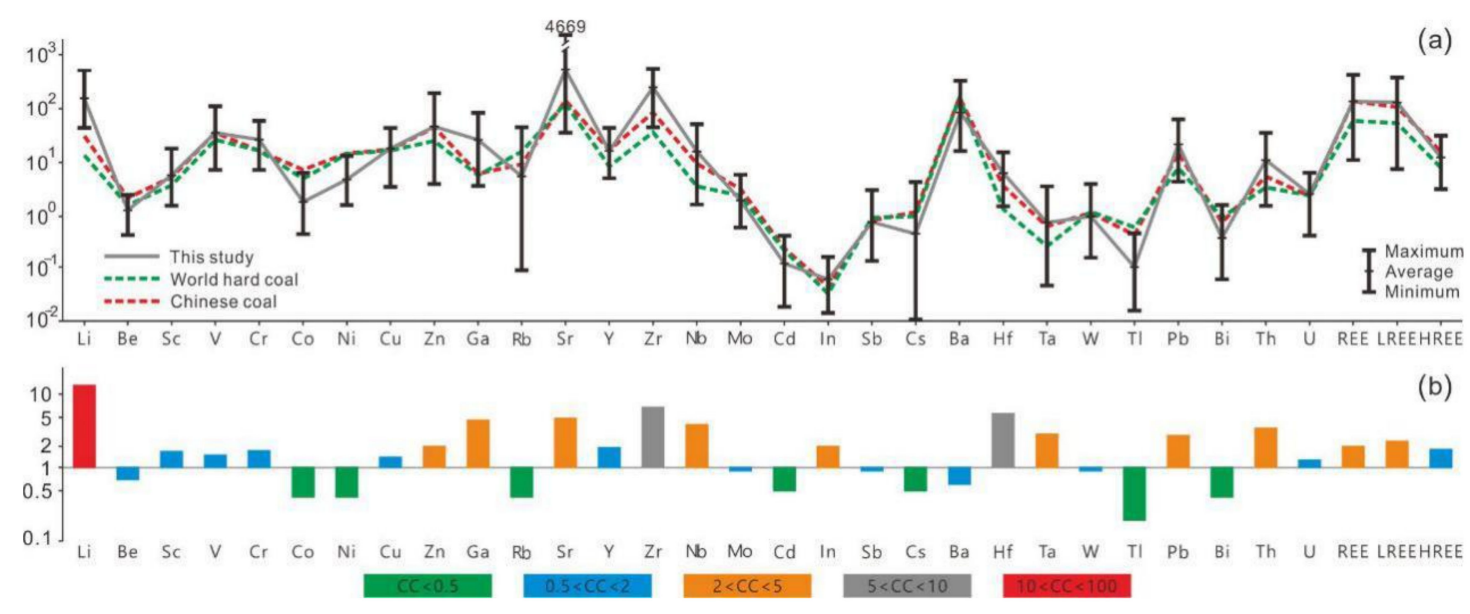

Figure 2. (a) Comparison of trace elements concentrations among No. 9 coals, the common Chinese coal [77] and the world hard coal [80], unit of ordinate was $\mu \mathrm{g} / \mathrm{g}$. (b) Concentration coefficients (CC) of trace elements in No. 9 coals, normalized by the World hard coals [80].

\subsubsection{Organic Constituents}

A total of eight samples covered the whole vertical range of No. 9 coals were selected for organic geochemical analysis, including n-alkanes and aromatic hydrocarbons (Table S5). The percentages of extractable organic matters (EOM) in the samples varied from $0.36 \%$ to $5.62 \%$, and averaged at $2.62 \%$. EOM were dominated by polar compounds and asphaltenes with a range of $65 \%$ to $84 \%$, and an average of $72.42 \%$. Saturated hydrocarbons ranged between $1.50 \%$ and $7.50 \%$, with an average of $2.62 \%$, while aromatic hydrocarbons were between $13.33 \%$ and $31.00 \%$, with an average of $23.86 \%$. The gas chromatograms showed that n-alkanes were mainly characterized as bimodal distribution pattern in which the peaks mainly distributed either at $\mathrm{nC}_{13}$ and $\mathrm{nC}_{16}-\mathrm{nC}_{18}$ in the upper horizons or at $\mathrm{nC}_{16}-$ $\mathrm{nC}_{18}$ and $\mathrm{nC}_{24}-\mathrm{nC}_{27}$ in the lower horizons (Figure S1). Identified aromatic hydrocarbons and their derivatives in No. 9 coals are listed Table S6. The ratios between the fractions of saturated hydrocarbons and aromatic hydrocarbons averaged at 0.16 , suggesting the dominant position of the latter.

\subsection{Source Apportionment of $\mathrm{Ga}$ and In}

During the coal-forming period of No. 9 coals, entire Ningwu Coalfield preformed as a sink of sedimentary materials that were transported from its surrounding provenances (Figure 1a). Previous studies inferred that terrestrial input mainly came from uplift and erosion areas of northwest and southeast, namely Yinshan Oldland, Lvliang Peninsula, and Wutai Island, respectively [65]. Delta alluvial plain was shifted into littoral tidal flat and lagoon by the influence of mutli-stage transgression that originated from the south during the Taiyuan Period [81]. Generally, No. 9 coals mainly formed in wet forest swamps and open mire [64].

Although diagenetic reforming and migration of chemical components could occur in sedimentation and diagenesis processes, some trace elements can still offer credible information of the sedimentary sources [82], especially those with lower water/rock partition coefficients and resultant strong immunity to fractionation can offer insight of their initial characteristics in provenance, such as Ti, Th, Hf, Y, U, Sc, Zr, and REE [83]. The relevant geochemical parameters and discrimination diagrams have been widely used to identify the sedimentary source [84,85]. In the plot of Hf against La/Th (Figure 3a), most of Ga-In-non-enriched samples distributed in felsic rock area, while Ga-In-enriched samples mainly dispersed in area of passive continental margin, showing a high proportion of old sediments. It indicated that source rocks of Ga-In-enriched horizons were derived 
from sedimentary rocks. Sun et al. [20] presented that the major provenance of coals in Taiyuan Formation in Ningwu Coalfield was Yinshan Oldland which provided a large amount of terrestrial clastic materials including bauxite in Benxi Formation. Thus, Ga and In enrichment in the top of No. 9 coals was related to weathering products (e.g., exogenous rounded euhedral boehmite) from Yinshan Oldland (Figure S2a). Diagram of La/Sc against $\mathrm{Co} /$ Th suggested that the samples mainly clustered around felsic volcanic rock and the rest dispersed near granite, indicating an acidic rock source (Figure $3 b$ ). It was reported that migmatized granite and granitic gneiss outcropped in Yinshan Oldland as well [86]. Average of Co/Th in No. 9 coals (0.31) was lower than the Chinese coal (1.21) and the World hard coal (1.55) due to enrichment of Th and depletion of Co. Cobalt is strong compatible element that trends to differentiate from magma in early stage of crystallization thus enrich in ultra-mafic and mafic plutons [87]. The depletion of Co in No. 9 coals suggested an absence of ultra-mafic and mafic sources. Therefore, the diagram demonstrated that felsic rocks was a provenance of No. 9 coals as well. Thorium is one of typical elements that are enriched in terrestrial weathering products [88], hence its enrichment could inherit the elemental characteristics of sedimentary rocks in Benxi Formation which could be an outcome of recycled sediments from Yinshan Oldland as well. In addition, factor analysis confirmed that $\mathrm{Ga}$ was significantly correlated with $\mathrm{Al}$ in Ga-enriched horizons $\left(R^{2}=0.9092\right)$, while opposite result occurred among other samples $\left(R^{2}=0.1889\right)$ (Figure $\left.4 a\right)$. It indicated that Ga-In-enriched horizons could be derived from weathering products of Al-enriched minerals, such as bauxite. Cluster analysis also showed that $\mathrm{Ga}$ was connected with $\mathrm{Al}$ in Cluster $\mathrm{F}$, and In had significant correlation with $\mathrm{Th}, \mathrm{Nb}$ and $\mathrm{Ta}$ in Cluster $\mathrm{D}$ (Figure 5). In contrary to $\mathrm{Co}, \mathrm{Th}, \mathrm{Nb}$, and $\mathrm{Ta}$ are typical incompatible elements that trend to accumulate in intermediate and felsic magma [87]. It indicated that In could originate from weathering products of felsic rocks as well. This result was in accordance with the diagrams, both of which proved that weathering products of bauxite of Benxi Formation in Yinshan Oldland could be the major source of Ga and In in No. 9 coals.
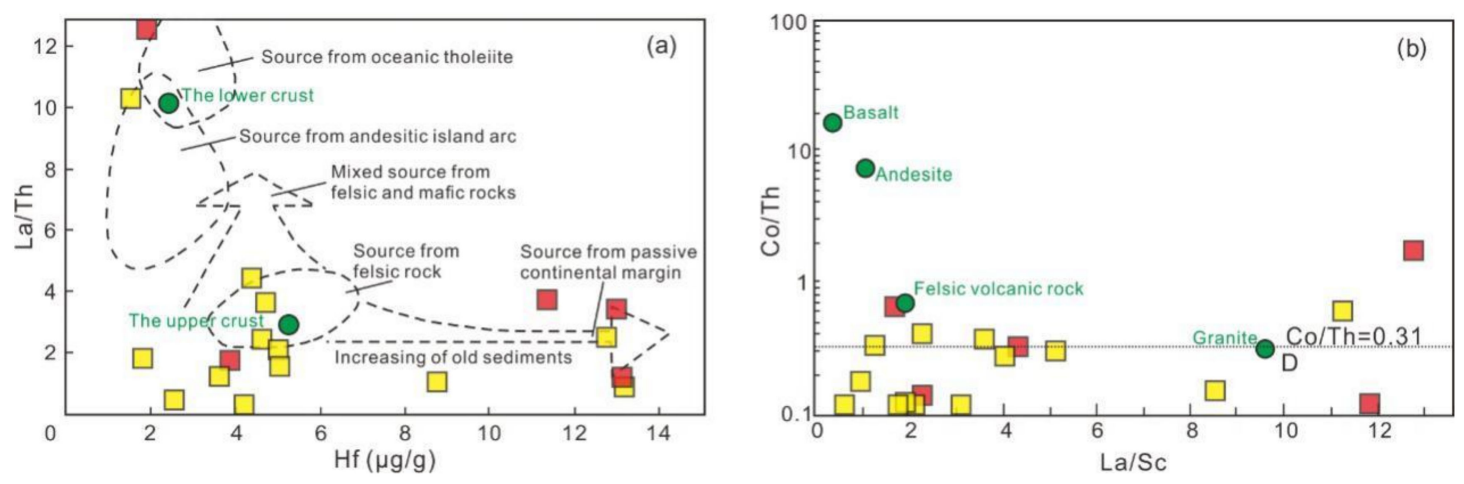

Figure 3. Diagrams of source apportionment for No. 9 coals. Red squares represented Ga-In-enriched horizons while yellow squares represented the rest of horizons. (a) was modified from Floyd and Leveridge [84]. (b) was modified from Gu et al. [89].

Normalized REE distribution patterns of No. 9 coals illustrated strong fractionation between light and heavy REE ( $\mathrm{L} / \mathrm{H}$ averaged at 7.79), significantly negative Eu anomaly ( $\delta$ Eu averaged at 0.57 ) and slightly negative Ce anomaly ( $\delta$ Ce averaged at 0.89 ), which were parallel to the patterns of bauxite of Benxi Formation in the regions, showing steep rightward slope and strong negative Eu anomaly (Figure S3). Europium remains stable in supergene process and its anomaly mainly inherits from source materials, thus Eu can provide information of provenance [90]. Yet. Ce in the bauxite presented both positive and negative anomaly with various extents, this discrepancy was likely caused by different redox condition in their sedimentary environment. The bauxite in Benxi Formation was a good carrier for enrichment of REE, with orders of magnitude of $10^{3}$ to $10^{4}(\mu \mathrm{g} / \mathrm{g})[91,92]$. The total REE contents in Ga-In-enriched horizons (averaged at $253.6 \mu \mathrm{g} / \mathrm{g}$ ) were much 
higher than Ga-In-non-enriched horizons (averaged at $70.1 \mu \mathrm{g} / \mathrm{g}$ ), indicating an increasing proportion of weathering products of bauxite in Ga-In enriched horizons.
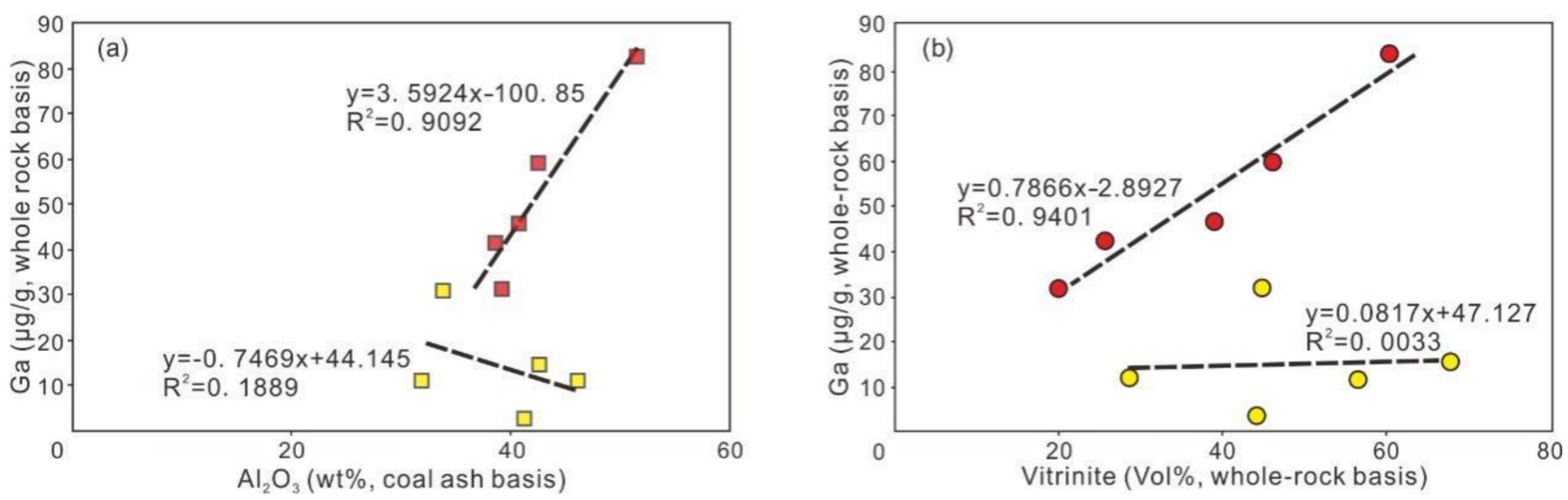

Figure 4. (a) Correlation between $\mathrm{Ga}$ and $\mathrm{Al}_{2} \mathrm{O}_{3}$. Red squares represented $\mathrm{Ga}$-In-enriched horizons while yellow squares represented the rest of horizons. (b) Correlation between Ga and vitrinite. Red circles represented Ga-In-enriched horizons while yellow circles represented the rest of horizons.

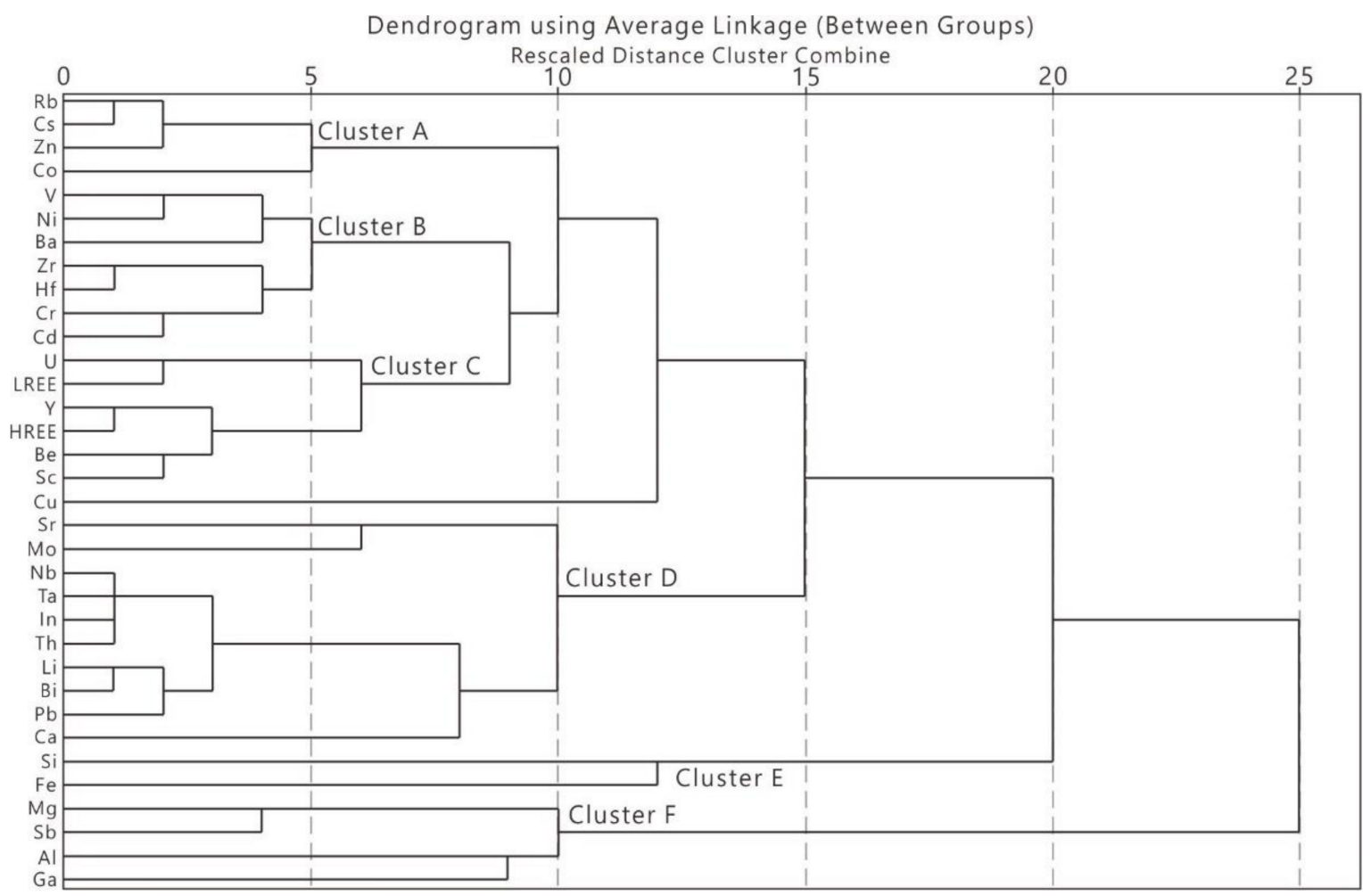

Figure 5. Dendrogram of HCA for Ga-In-enriched horizons (Measurement criteria: Pearson's correlation coefficient, $\mathrm{n}=5$ ).

\subsection{Sedimentary Environment Favoring Enrichment of Ga and In}

Enrichment of elements is suppose to be a synergistic complex generated from adequate material supplies in company with appropriate accumulation conditions. Since the bauxite of Benxi Formation in Yinshan Oldland was recognized as material basis of Ga and In enrichment in No. 9 coals, identifying their favourable environmental conditions was of necessity as well. In other words, abundant Ga and In were transported into peat bog during peat accumulation of No. 9 coals then precipitated and accumulated to reach the enrichment level due to proper conditions, otherwise they would migrate out of the system. 
The ratio of $\mathrm{Th} / \mathrm{U}$ can indicate weathering intensity suffered by sediments $[93,94]$. The ratios in No. 9 coals were between 0.50 and 8.20, with an average of 4.26, suggesting incompletely weathering throughout the seams. The upper horizons (AJ03-AJ05), however, presented higher Th/U ratios which were representative of intensive laterization (Table 2). This was likely caused by occurrence of strongly weathered detritus, i.e., aforementioned bauxite in Benxi Formation. Contrasted with Th that is relatively insoluble under supergene condition, $\mathrm{U}$ is liable to be oxidated from $\mathrm{U}^{4+}$ to $\mathrm{U}^{6+}$ under oxic condition so that it is difficult to accumulate in the sediments $[95,96]$. Thus, higher Th/U ratios in Ga-In-enriched horizons demonstrated that $\mathrm{Ga}$ and In trended to be enriched under oxidation condition. This was in accordance with results of $\delta \mathrm{Ce}$ and $\mathrm{Pr} / \mathrm{Ph}$ ratios. As a redox sensitive element, Ce can be oxidized to $\mathrm{Ce}^{4+}$ from $\mathrm{Ce}^{3+}$ under oxidizing condition, which leads to separation of Ce from LREE due to the formation of insoluble hydroxide of $\mathrm{Ce}^{4+}$ [97]. Cerium anomaly is widely employed as an indicator of redox condition in sedimentary environment. Slightly negative Ce anomaly demonstrated a weak oxidative condition during peat accumulation of No. 9 coals. Average $\delta$ Ce in Ga-In-enriched horizons except AJ05 (0.81) was lower than Ga-In-non-enriched horizons (0.91) suggested a stronger oxidation condition in Ga-Inenriched horizons, while positive Ce anomaly in AJ05 was likely caused by depletion of $\Sigma$ REE in AJ05 with a concentration of $37.39 \mu \mathrm{g} / \mathrm{g}$ compared with the average of No. 9 coals $(121.10 \mu \mathrm{g} / \mathrm{g})$.

The ratio of pristane to phytane $(\mathrm{Pr} / \mathrm{Ph})$ is a useful index with redox sensitivity because of opposite pathways of chemical conversion from phytol (their common precursor) into pristane (oxidation) or phystane (reduction) [98,99]. The $\mathrm{Pr} / \mathrm{Ph}$ ratios in the samples ranged between 1.58 and 4.81, with an average of 2.76, indicating a weak oxidative condition. Considering that organic matters in No. 9 coals were characterized as low maturity due to the dominance of polar compounds and asphaltenes (Table S5), excessively high $\mathrm{Pr} / \mathrm{Ph}$ ratio (Table 2), such as AJ02 (4.81), may roughly indicate input of terrestrial higher plant rather than a strong oxidative condition [100]). $\mathrm{Pr} / \mathrm{nC}_{17}$ coupled with $\mathrm{Ph} / \mathrm{nC}_{18}$ can be used for recognizing redox condition, forming environment and type of input materials [101]. Their ratios were distributed in a range of $0.81-3.87$ and $0.52-0.91$, respectively (Table 2 ). The cross plot indicated that organic matters from terrestrial and mixed sources accumulated under oxidation condition (Figure S4a), which was in conformity with results of $\delta \mathrm{Ce}$ and $\mathrm{Pr} / \mathrm{Ph}$ ratios (Table 2). In addition, gas chromatograms of aromatic hydrocarbons illustrated that contents of phenanthrene (Phe), fluoranthene (Flu) and pyrene (Pyr) were characterized by an increasing trend from bottom to top in No. 9 coals (Figure 6). Some studies in Jungar Basin suggested that Phe, Flu, and Pyr, including their derivatives, were typical biomarkers of terrestrial higher plants [102]. Similarly, contents of naphthalenes and alkylated naphthalenes varied the same trend on vertical scale, indicating an increasing load of terrestrial higher plants [103]. In addition, perylene was identified in No. 9 coals. As a controversial aromatic hydrocarbon, perylene was mainly recognized to derive from degradation of marine organism [104,105], terrestrial fungal degradation [106,107], and wildfires [108,109]. In the case of No. 9 coals, a trace amount of funginite and absence of alginite (Table 1) represented weak activity of wood-degrading fungi and algae, and oxidation condition was inappropriate for forming of diagenetic perylene which was considered to be an exclusive indicator of reducing condition [110]. Presence of perylene in No. 9 coals revealed input of terrestrial higher plants because perylene derived from wildfire that formed during higher-temperature combustion that occurred in the case of crown fire of arbors [111]. There was a positive correlation between $\mathrm{Ga}$ and vitrinite $\left(\mathrm{R}^{2}=0.9401\right)$ in Ga-In-enriched horizons (Figure 4 b). Generally, vitrinite was recognized to originate from humic acid that further originated from gelification of wood tissue [112,113]. Not only did cell structures (cavities) in telinite provide space for mineral precipitation and occurrence of detritus in which Ga and In could host (e.g., endogenous amorphous kaolinite) (Figure S2b), but also colloidal property of vitrinite was conducive to absorption of Ga and In cations when weathering solutions were transported into peat bog. Additionally, cracked 
cell structures in semifusinite can also provide the space (Figure S2c). This indicated that terrestrial higher plants had positive effect on ultimate enrichment of Ga and In.

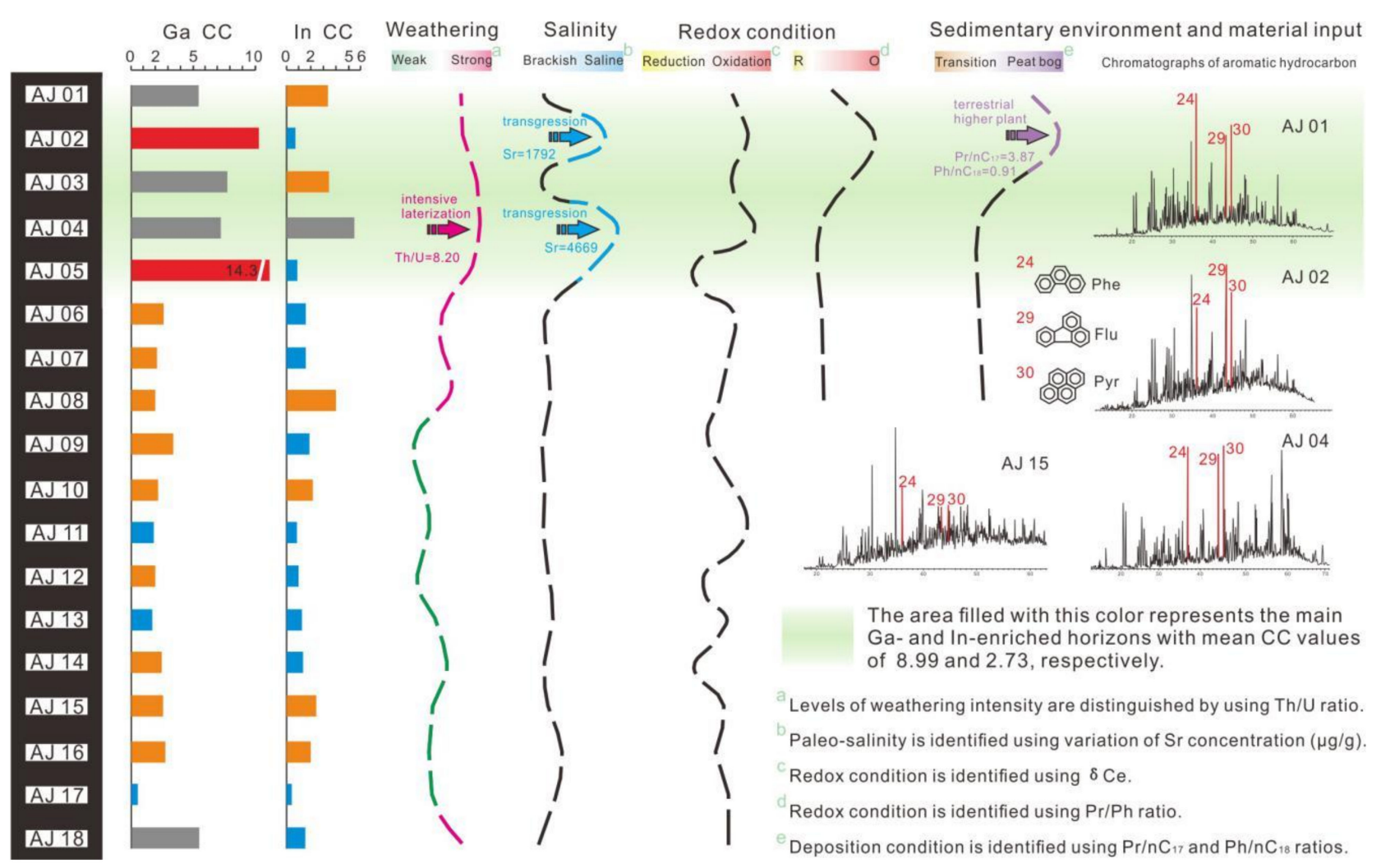

Figure 6. Discrimination diagram for sedimentary environment favoring enrichment of Ga and In in No. 9 coals. (a) Weathering intensity is identified by Th/U ratio of which classification scheme was recommended by Wignall and Twitchett (1996) [94]. (b) Paloe-salinity is identified by variation of Sr concentration of which classification scheme was recommended by Deng and Qian (1994) [114]. (c) Redox condition is identified by the parameter $\delta$ Ce of which classification scheme was recommended by Lee and Byrne (1992) [97]. (d) Redox condition is also identified by $\mathrm{Pr} / \mathrm{Ph}$ ratio of which classification scheme was available in Hu et al. (2000) and Bao et al. (2016) $[115,116]$. (e) Deposition condition is identified by $\operatorname{Pr} / \mathrm{nC}_{17}$ ratio coupled with $\mathrm{Ph} / \mathrm{nC}_{18}$ ratio of which classification scheme was available in Meng et al. (2004) [117].

It was reported that Daning Gulf (Figure 1a) was suffered from multi-stage transgressions that initiated in Pennsylvanian [65]. As shown in Figure 6, twice evident elevations of $\mathrm{Sr}$ concentrations occurred in Ga-In-enriched horizons. It was reported that $\mathrm{Sr}$ enriched in saline water with higher concentrations [114]. Additionally, Th can be used to evaluate the salinity, which the decrease of the former indicated the increase of the latter [118]. Concentrations of $\mathrm{Sr}$ and Th reflected that most of samples in No. 9 coals were influenced by sea water, while Ga-In-enriched horizons underwent intensive transgressions (Figure S4b). Gallium and In generally occurs in +3 oxidation state in aqueous solution, and their precipitation and migration highly depend on $\mathrm{pH}$ [119]. In the process of transgressions, therefore, intrusive sea water with higher $\mathrm{pH}$ value led to increasing of $\mathrm{pH}$ value in Ga-Inenriched horizons, then incurred precipitation of Ga- and In-bearing minerals (Figure S2d) from aqueous solutions into peat sediments.

\section{Discussion on Potential Health Risks of Enriched Ga and In in Coal}

It was known that operations of coal mining, such as drilling, excavation, blasting, cleaning, transportation, and storing, may severely contaminate ambient environment and inflict human health to their threaten. In the operation processes, a huge amount of particulate matters (PM) can be released into atmosphere [120,121], which together with particulate-bound trace elements were recognized as one of major parts of global health 
issues regarding pathopoiesis of pulmonary diseases, cardiovascular diseases, kidney diseases, carcinomas, and etc. [122-127]. It was reported that coal worker's pneumoconiosis (CWP) was mainly caused by inhalation of PM in the processes of coal mining [29,128]. In Appalachian coal mining areas, local residents were suffered from higher probability of diseases due to PM that generated from mountaintop coal mines [121,129,130]. Cardoso et al. [131] reported that $1 \%$ of the whole coal miners in Columbia were diagnosed with CWP. Another main coal-related process releasing PM is coal-based thermal power generation. There are two types of products after combustion, one of which is coal fly ash (CFA) that generally accounts for $65-95 \mathrm{wt} \%$ of residual materials [132]. It has been confirmed that CFA conducts as a carrier of hazardous trace elements (HTEs) [133,134]. Although fabric filter or electrostatic precipitator had been widely equipped in smokestacks of power plants, PM with various assemblies of HTEs caused by CFA releasing still resulted in high risk on atmospheric environment and human health [135-139]. Dwivedi et al. [140] found that oxidative DNA damage in human cells was attributed to nanoscale CFA. Inhalation of PM caused by CFA releasing is also linked to pulmonary diseases, lung carcinoma, immunocompromise, cardiovascular diseases, and reproductive disorders [141]. In general, lung tissues are principal parts for PM accumulation in human body. Accordingly, toxicity of $\mathrm{Ga}$ and In primarily affects lung tissues as well [43]. Considering that adverse impacts of coal-related PM on human health depend on its chemical components [142,143], enrichment of Ga and In in No. 9 coals inevitably has influences on human health. For coal miners and local residents of Anjialing coal mine, they could undergo severe exposure to PM caused by coal mining operations of which opencast method may aggravate dust emission [144]. To date limited case about $\mathrm{Ga}$ and In toxicosis related with coal has been reported, but cases from electronics manufacturing workplace revealed that chronic exposure to Ga- and In-contained airborne dust could induce various diseases $[50,57,145]$. For workers and nearby residents of coal-fired power plants that use the No. 9 coals as feed coal, CFA may lead to more adverse impacts on health because of its characteristics that HTEs are prone to be enriched in CFA in which concentrations of certain metals can elevate 10 times as in raw coal $[146,147]$. In the cases of Ga and In, they may perform as partially volatile elements that tend to be emitted into the environment in the forms of fly ash and flue gas during coal combustion [27] because of their low melting points of $29.8^{\circ} \mathrm{C}$ and $156.51{ }^{\circ} \mathrm{C}$, respectively. No. 9 coals in Anjialing surface mine were classified as medium-ash coal with average ash yield on dry basis of $22.95 \%$. Therefore, adequate attention to potential health impacts of Ga and In enrichment in No. 9 coals in Anjialing surface mine, and more specifically the exposure level of affected population, as well as migration mechanisms and stack emission of $\mathrm{Ga}$ and In during the combustion, should be paid imminently.

In addition, recycling and improper disposal of by-products generated from coal industry may exacerbate health hazards of Ga and In. For example, the utilization of CFA in China included subgrade construction, soil modifier and production of cement, concrete and brick [134,147], while a considerable quantity of CFA was stored in ponds, landfills and dumps [148]. All of these can result in releasing of HTEs, which contaminates the soil and water on account of the leachability of HTEs in CFA. Similarly, HTEs in coal cleaning rejects (CCR), including coal gangue and water treatment sludge, will be leached if these wastes are exposed to the air. Studies corroborated that Ga and In can be taken up by plants from environmental media $[49,52,149]$. Therefore, food chain could be a critical junction of pathway that $\mathrm{Ga}$ and In enter the human body. Besides major adverse effects on lungs via inhalation, Ga and In can accumulate in stomach and kidney, and affect them detrimentally $[53,61]$. Thus, in the processes of comprehensive utilization and disposal of by-products of No. 9 coals, prevention on migration of Ga and In into environmental media and further to food chain is also necessary.

Special threshold about Ga and In exposure and contamination is still lack or outdated, to our best knowledge, there were three occupational exposure limits of In and its compounds, which were $0.1 \mathrm{mg} / \mathrm{m}^{3}$ for time weight average of air indium recommended by the Departments of Labor in United States (1993) [58], $3 \mu \mathrm{g} / 1$ for serum indium recommended 
by the Japan Society for Occupational Health (2007) [150], and $0.1 \mathrm{mg} / \mathrm{m}^{3}$ for permissible concentration: time weighted average and $0.3 \mathrm{mg} / \mathrm{m}^{3}$ for permissible concentration: short term exposure limit recommended by the National Health Commission of the P.R.C. [151] Furthermore, carcinogenic and non-carcinogenic risk of Ga and In in coal, soil, water, and atmospheric particulate cannot be quantitatively evaluated because of the lack of available toxic parameters of $\mathrm{Ga}$ and $\mathrm{In}$, which is also a problem that needs to be solved.

\section{Conclusions}

Gallium and In were mainly enriched in the upper horizons of No. 9 coal seams in Anjialing surface mine, which Ga can reach significant enrichment level and In can reach enrichment level. Diagrams of Hf vs. La/Th and $\mathrm{La} / \mathrm{Sc}$ vs. Co/Th and distribution patterns of chondrite-normalized REE abundances indicated that Ga and In were chiefly derived from terrestrial weathering products of bauxite in Benxi Formation in Yinshan Oldland while felsic magmatic rocks outcropped in Yinshan Oldland could contribute to In enrichment in No. 9 coals partly, which was in conformity with the conclusion of hierarchical cluster analysis.

Several ratios, such as $\mathrm{Th} / \mathrm{U}, \mathrm{Pr} / \mathrm{Ph}$, and $\delta \mathrm{Ce}$, indicated the trend that $\mathrm{Ga}$ and In were enriched under weak oxidation condition. This conclusion was also comfirmed by the diagram of $\mathrm{Pr} / \mathrm{nC}_{17} \mathrm{vs}$. $\mathrm{Ph} / \mathrm{nC}_{18}$. It was obvious that elevated concentrations of Phe, Flu and Pyr occurred in Ga-In-enriched horizons. Phenanthrene, Flu and Pyr were recognized as typical biomarkers of terrestsrial higher plants. Moreover, there was a positive correlation between Ga and vitrinite in Ga-In-enriched horizons. Photomicrograph demostrated that cell structures of higher plants could provide space for Ga and In enrichment. Additionally, variations of Sr and Th concentrations showed that multi-stage transgression is also beneficial to $\mathrm{Ga}$ and In enrichment.

Gallium and In in coal and byproducts related to coal processing and utilization had been studied by numerous scholars, which focused on their economic values. However, knowledge on toxicity of Ga and In was gradually acquired on account of increasing cases of occupational exposure and diseases among electronic manufacturing workers due to raw material containing Ga and In. Given the huge yield and consumption of coal and its potential environmental menace, the enrichment of Ga and In in coal should be taken into account in respect of their risks on environment and human health as well. Coal mining operations and combustion can release a large amount of atmospheric particulate matters, which could be a pathway that Ga and In migrate from coal to human respiratory system. Accumulation of Ga and In in lung tissues could induce various diseases, including pulmonary alvoelar proteinosis, pneumonia, lung cancer, and etc. Inappropriate disposal and utilization of coal cleaning rejects and coal combustion products may also lead to threats of $\mathrm{Ga}$ and In on human health through food chain. Thus, the migration regularity of Ga and In in No. 9 coals needs to be studied in further studies, because understanding the relationship between coal, environmental media, and human daily intake is of paramount importance for the prevention and control of their risks.

Supplementary Materials: The following are available online at https://www.mdpi.com/2075 -163X/11/1/64/s1. Section S1: Analytic methods, Section S2: Calculation formulas, Figure S1: Gas chromatograms of saturated hydrocarbons from selected samples in No. 9 coals, Figure S2: Photomicrographs of minerals in Ga-In-enriched horizons of No. 9 coals, Figure S3: Chondritenormalized abundances of REE for Ga-In-enriched horizons in No. 9 coals, Figure S4: Cross plots of $\mathrm{Ph} / \mathrm{nC}_{17}$ vs. $\mathrm{Pr} / \mathrm{nC}_{18}$ and Th vs. Sr, Table S1: Statistical results of proximate analysis and ultimate analyses and gross calorific values of No. 9 coals, Table S2: Concentrations of major elements in No. 9 coals, Table S3: Concentrations of trace elements in No. 9 coals, Table S4: Concentrations of REE in No. 9 coals, Table S5: Extractable organic matter yield and relative proportion of saturated hydrocarbons, aromatic hydrocarbons, polar compounds and asphaltene of selected samples in No. 9 coals, Table S6: List of identified aromatic hydrocarbons and their derivatives in selected samples in No. 9 coals. 
Author Contributions: Conceptualization: M.Z., J.W., and Y.S.; data curation: H.H. and L.T.; formal analysis: Y.L. and H.H.; investigation: L.T., Y.L., and Y.S.; methodology: M.Z., J.W., and Y.S.; project administration: Y.S.; writing-original draft: M.Z. and H.H.; writing-review \& editing: Y.S. All authors have read and agreed to the published version of the manuscript.

Funding: This study is financially supported by the National Natural Science Foundation of China (Nos. 41330317 and 41641019).

Institutional Review Board Statement: Not applicable.

Informed Consent Statement: Not applicable.

Data Availability Statement: The data presented in this study are available in Supplementary Material here.

Acknowledgments: The authors would like to thank Jing Zhao, Jing $\mathrm{Xu}$ and Xiaoli Deng for their assistance in the experimental analyses. We also gratefully thank the editors and anonymous reviewers for their comments that help to improve the manuscript.

Conflicts of Interest: The authors declare that they have no competing interests.

\section{References}

1. Liu, T.; Liu, S. The impacts of coal dust on miners' health: A review. Environ. Res. 2020, 190, 109849. [CrossRef]

2. International Energy Agency (IEA). Coal Information: Overview. 2020. Available online: https://www.iea.org/reports/coalinformation-overview (accessed on 29 September 2020).

3. Wang, X.; Wang, X.; Pan, Z.; Pan, X.; Chai, P.; Pan, S.; Yang, Q. Mineralogical and geochemical characteristics of the Permian coal from the Qinshui Basin, northern China, with emphasis on lithium enrichment. Int. J. Coal Geol. 2019, 214, 103254. [CrossRef]

4. World Coal Association (WCA). Uses of Coal. 2019. Available online: https://ww.worldcoal.org/coal/use-coal (accessed on 29 September 2020).

5. Dai, S.; Bechtel, A.; Eble, C.F.; Flores, R.M.; French, D.; Graham, I.T.; Hood, M.M.; Hower, J.C.; Korasidis, V.A.; Moore, T.A.; et al. Recognition of peat depositional environments in coal: A review. Int. J. Coal Geol. 2020, 219, 103383. [CrossRef]

6. Dai, S.; Finkelman, R.B. Coal as a promising source of critical elements: Progress and future prospects. Int. J. Coal Geol. 2018, 186, 155-164. [CrossRef]

7. Lin, R.; Soong, Y.; Granite, E.J. Evaluation of trace elements in U.S. coals using the USGS COALQUAL database version 3.0. Part I: Rare earth elements and yttrium (REY). Int. J. Coal Geol. 2018, 192, 1-13. [CrossRef]

8. Lin, R.; Soong, Y.; Granite, E.J. Evaluation of trace elements in U.S. coals using the USGS COALQUAL database version 3.0. Part II: Non-REY critical elements. Int. J. Coal Geol. 2018, 192, 39-50. [CrossRef]

9. Granite, E.J.; Roth, E.; Alvin, M.A. Recovery of rare earths from coal and by-products-A paradigm shift for coal research. Bridge. Natl. Acad. Eng. 2016, 46, 56-57.

10. Zhuang, X.; Querol, X.; Alastuey, A.; Juan, R.; Plana, F.; Lopez-Soler, A.; Du, G.; Martynov, V.V. Geochemistry and mineralogy of the Cretaceous Wulantuga high-germanium coal deposit in Shengli coal field, Inner Mongolia, northeastern China. Int. J. Coal Geol. 2006, 66, 119-136. [CrossRef]

11. Dai, S.; Jiang, Y.; Ward, C.R.; Gu, L.; Seredin, V.V.; Liu, H. Mineralogical and geochemical compositions of the coal in the Guanbanwusu Mine, Inner Mongolia, China: Further evidence for the existence of an $\mathrm{Al}$ (Ga and REE) ore deposit in the Jungar Coalfield. Int. J. Coal Geol. 2012, 98, 10-40. [CrossRef]

12. Dai, S.; Wang, X.; Seredin, V.V.; Hower, J.C.; Ward, C.R.; O’Keefe, J.M.K.; Huang, W.; Li, T.; Li, X.; Liu, H.; et al. Petrology, mineralogy, and geochemistry of the Ge-rich coal from the Wulantuga Ge ore deposit, Inner Mongolia, China: New data and genetic implications. Int. J. Coal Geol. 2012, 90-91, 72-99. [CrossRef]

13. Li, J.; Zhuang, X.; Querol, X.; Font, O.; Izquierdo, M.; Wang, Z. New data on mineralogy and geochemistry of high-Ge coals in the Yimin coalfield, Inner Mongolia, China. Int. J. Coal Geol. 2014, 125, 10-21. [CrossRef]

14. Seredin, V.V.; Finkelman, R.B. Metalliferous coals: A review of the main genetic and geochemical types. Int. J. Coal Geol. 2008, 76, 253-289. [CrossRef]

15. Seredin, V.V.; Dai, S.; Sun, Y.; Chekryzhov, I.Y. Coal deposits as promising sources of rare metals for alternative power and energy-efficient technologies. Appl. Geochem. 2013, 31, 1-11. [CrossRef]

16. Dai, S.; Yan, X.; Ward, C.R.; Hower, J.C.; Zhao, L.; Wang, X.; Zhao, L.; Ren, D.; Finkelman, R.B. Valuable elements in Chinese coals: A review. Int. Geol. Rev. 2016, 60, 590-620. [CrossRef]

17. Sun, Y.; Li, Y.; Zhao, C.; Lin, M.; Wang, J.; Qin, S. Concentrations of lithium in Chinese coals. Energy Explor. Exploit. 2010, 28, 97-104. [CrossRef]

18. Sun, Y.; Zhao, C.; Li, Y.; Wang, J.; Liu, S. Li distribution and mode of occurrences in Li-bearing coal seam \#6 from the Guanbanwusu Mine, Inner Mongolia, northern China. Energy Explor. Exploit. 2012, 30, 109-130.

19. Sun, Y.; Zhao, C.; Li, Y.; Wang, J.; Zhang, J.; Jin, Z.; Lin, M.; Kalkreuth, W. Further information of the associated Li deposits in the No. 6 coal seam at Jungar Coalfield, Inner Mongolia, Northern China. Acta Geol. Sinica Engl. Ed. 2013, 87, 801-812. [CrossRef] 
20. Sun, Y.; Zhao, C.; Li, Y.; Wang, J.; Lin, M. Li distribution and mode of occurrences in Li-bearing Coal Seam from Pingshuo Mining District, Ningwu Coalfield, northern China. Energy Explor. Exploit. 2013, 31, 27-38. [CrossRef]

21. Sun, Y.; Zhao, C.; Zhang, J.; Yang, J.; Zhang, Y.; Yuan, Y.; Xu, J.; Duan, D. Concentrations of valuable elements of the coals from the Pingshuo Mining District, Ningwu Coalfield, northern China. Energy Explor. Exploit. 2013, 31, 727-744. [CrossRef]

22. Torralvo, F.A.; Fernández-Pereira, C.; Campanario, M.C. Recovery of germanium from aqueous solutions by ion-exchange extraction of its catechol complex. Ind. Eng. Chem. Res. 2010, 49, 4817-4823. [CrossRef]

23. Fang, Z.; Gesser, H.D. Recovery of gallium from coal fly ash. Hydrometallurgy 1996, 41, 187-200. [CrossRef]

24. Zhao, Z.; Cui, L.; Guo, Y.; Li, H.; Cheng, F. Recovery of gallium from sulfuric acid leach liquor of coal fly ash by stepwise separation using P507 and Cyanex 272. Chem. Eng. J. 2020, 381, 122699. [CrossRef]

25. Zhao, F.; Ren, D. Study on leaching experiment of hazardous trace elements in coal-fired residues: Review. Coal Geol. Explor. 1998, 26, 14-17, (In Chinese with English abstract).

26. Senior, C. Mercury behavior in coal combustion systems. In Mercury Control for Coal-Derived Gas Streams; Granite, E.J., Pennline, H.W., Senior, C., Eds.; Wiley-VCH: Weinheim, Germany, 2015; ISBN 978-3-527-65881-7.

27. Senior, C.L.; Granite, E.J.; Linak, W.P.; Seames, W. Chemistry of trace inorganic elements in coal combustion systems: A century of discovery. Energy Fuels 2020, 34, 15141-15168. [CrossRef]

28. Ding, Z.; Zheng, B.; Zhang, J.; Long, J.; Belkin, H.E.; Finkelman, R.B.; Zhou, D.; Zhou, Y. Geological and geochemical characteristics of high arsenic coals from endemic arsenosis areas in southwestern Guizhou Province, China. Appl. Geochem. 2001, 16, 1353-1360. [CrossRef]

29. Finkelman, R.B.; Orem, W.; Castranova, V.; Tatu, C.A.; Belkin, H.E.; Zheng, B.; Lerch, H.E.; Maharaj, S.V.; Bates, A.L. Health impacts of coal and coal use: Possible solutions. Int. J. Coal Geol. 2002, 50, 425-443. [CrossRef]

30. Zhang, Y.; Cao, S. Coal burning induced endemic fluorosis in China. Fluoride 1996, 29, 207-211.

31. Luo, K.; Ren, D.; Xu, L.; Dai, S.; Cao, D.; Feng, F.; Tan, J. Fluorine content and distribution pattern in Chinese coals. Int. J. Coal Geol. 2004, 57, 143-149. [CrossRef]

32. Luo, K.; Li, H.; Feng, F.; Chen, T.; Xiong, M.; Wang, W.; Liao, X.; Li, W.; Wang, L. Content and distribution of fluorine in rock, clay and water in fluorosis area Zhaotong, Yunnan Province. J. China Coal Soc. 2007, 32, 363-367, (In Chinese with English Abstract).

33. Sun, Y. Geochemical study advance about fluorine in coal and "coal-burning" endemic fluorosis from western Guizhou. Bull. Mineral. Petrol. Geochem. 2005, 24, 350-356, (In Chinese with English abstract).

34. Mao, D.; Su, H. Geographic factors of selenosis in Exi Autonomous Prefecture. Prev. Med. Bull. Hubei Prov. 1993, 4, 23-25. (In Chinese)

35. Mao, D.; Zheng, B.; Su, H. The medical geography characteristics of Se-poisoning in Yuyangba. Endemic Dis. Bull. 1997, 12, 59-61, (In Chinese with English Abstract). [CrossRef]

36. Zheng, B.; Hong, Y.; Zhao, W.; Zhou, H.; Xia, W.; Su, H.; Mao, D.; Yan, L.; Thornton, I. The Se-rich carbonaceous siliceous rock and endemic selenosis in southwest Hubei, China. Chin. Sci. Bull. 1992, 37, 1725-1729. [CrossRef]

37. National Bureau of Statistics of the People's Republic of China (NBSPRC). Statistical Communique of the People's Republic of China on the 2019 National Economic and Social Development. 2020. Available online: http://www.stats.gov.cn/tjsj/zxfb/2020 02/t20200228_1728913.html (accessed on 29 September 2020).

38. Liu, X.; Qin, Y.; Wang, W. Occurrence and geological controls of gallium in coal from Xingjiashe, Gujiao Mining District, Shanxi. Coal Geol. Explor. 2009, 37, 18-21, (In Chinese with English abstract). [CrossRef]

39. Gao, Y.; Guo, Y. The distribution and enrichment mechanism of Gallium in coal North Hedong Coalfield. Energy Technol. Manage. 2012, 1, 111-113, (In Chinese with English abstract).

40. Qin, S.; Sun, Y.; Li, Y.; Wang, J.; Zhao, C.; Gao, K. Coal deposits as promising alternative sources for gallium. Earth Sci. Rev. 2015, 150, 95-101. [CrossRef]

41. Zhu, H.; Chen, H.; Zhang, W.; Ning, S.; Han, L. Metal mineral types and distribution characteristics in coal in Northern China. J. China Coal Soc. 2016, 41, 303-309, (In Chinese with English abstract). [CrossRef]

42. Zhang, J.; Zheng, C.; Ren, D.; Chou, C.; Liu, J.; Zeng, R.; Wang, Z.; Zhao, F.; Ge, Y. Distribution of potentially hazardous trace elements in coals from Shanxi province, China. Fuel 2004, 83, 129-135. [CrossRef]

43. White, S.J.O.; Shine, J.P. Exposure potential and health impacts of indium and gallium, metals critical to emerging electronics and energy technologies. Curr. Environ. Health Rep. 2016, 3, 459-467. [CrossRef]

44. Frenzel, M.; Ketris, M.; Seifert, T.; Gutzmer, J. On the current and future availability of gallium. Resour. Policy 2016, 47, 38-50. [CrossRef]

45. White, S.J.O.; Hemond, H.F. The anthrobiogeochemical cycle of indium: A review of the natural and anthropogenic cycling of indium in the environment. Crit. Rev. Environ. Sci. Technol. 2012, 42, 155-186. [CrossRef]

46. Mastalerz, M.; Drobniak, A. Gallium and germanium in selected Indiana coals. Int. J. Coal Geol. 2012, 94, 302-313. [CrossRef]

47. Hecker, S. Plutonium and its alloys-From atoms to microstructure. Los Alamos Sci. 2000, 26, $290-335$.

48. Chitambar, C.R. Medical applications and toxicities of gallium compounds. Int. J. Environ. Res. Public Health 2010, 7, $2337-2361$. [CrossRef] [PubMed]

49. Chang, H.F.; Wang, S.L.; Lee, D.C.; Hsiao, S.S.Y.; Hashimoto, Y.; Yeh, K.C. Assessment of indium toxicity to the model plant Arabidopsis. J. Hazard. Mater. 2020, 387, 121983. [CrossRef]

50. Bomhard, E.M. The toxicology of indium oxide. Environ. Toxicol. Phar. 2018, 58, 250-258. [CrossRef] 
51. Wedepohl, H. The composition of the continental crust. Geochim. Cosmochim. Acta 1995, 59, 1217-1239. [CrossRef]

52. Jensen, H.; Gaw, S.; Lehto, N.J.; Hassall, L.; Robinson, B.H. The mobility and plant uptake of gallium and indium, two emerging contaminants associated with electronic waste and other sources. Chemosphere 2018, 209, 675-684. [CrossRef]

53. Tanaka, A. Toxicity of Indium arsenide, gallium arsenide, and aluminium gallium arsenide. Toxicol. Appl. Pharmacol. 2004, 198, 405-411. [CrossRef]

54. Goering, P.L.; Maronpot, R.R.; Fowler, B.A. Effect of intratracheal gallium arsenide administration on Delta-aminolevulinic acid dehydratase in rats: Relationship to urinary excretion of aminolenulinic acid. Toxicol. Appl. Pharmacol. 1988, 92, 179-193. [CrossRef]

55. Webb, D.R.; Wilson, S.; Carter, D. Pulmonary clearance and toxicity of respirable gallium arsenide particulates intratracheally instilled into rats. Am. Ind. Hyg. Assoc. J. 1987, 48, 660-667. [CrossRef] [PubMed]

56. Sikorski, E.E.; McCay, J.A.; White, K.L.; Bradley, S.G.; Munson, A.E. Immunotoxicity of the semiconductor gallium arsenide in female B6C3F1 mice. Fundam. Appl. Toxicol. 1989, 13, 843-858. [CrossRef]

57. Tsao, Y.C.; Fan, H.Y.; Luo, J.C.J. Case reports of indium lung disease in Taiwan. J. Formos. Med. Assoc. 2020, in press. [CrossRef] [PubMed]

58. Liu, H.H.; Chen, C.Y.; Chen, G.I.; Lee, L.H.; Chen, H.L. Relationship between indium exposure and oxidative damage in workers in indium tin oxide production plants. Int. Arch. Occup. Environ. Health 2012, 85, 447-453. [CrossRef]

59. Nakano, K.; Nishizawa, T.; Umeda, Y.; Kasai, T.; Noguchi, T.; Gotoh, K.; Ikawa, N.; Eitaki, Y.; Kawasumi, Y.; Yamauchi, T.; et al. Inhalation carcinogenicity and chronic toxicity of indium-tin oxide in rats and mice. J. Occup. Health 2011, 53, 175-187. [CrossRef]

60. Cummings, K.J.; Nakano, M.; Omar, K.; Takeuchi, K.; Chonan, T.; Xiao, Y.; Harley, R.A.; Roggli, V.L.; Hebisawa, A.; Tallaksen, R.J.; et al. Indium lung disease. Chest 2012, 141, 1512-1521. [CrossRef]

61. Andersen, J.C.Ø.; Cropp, A.; Paradise, D.C. Solubility of indium-tin oxide in simulated lung and gastric fluids: Pathways for human intake. Sci. Total Environ. 2017, 579, 628-636. [CrossRef]

62. Wang, J.; Wang, Q.; Tian, L. Characteristics of trace elements of the No. 9 coal seam from the Anjialing Mine, Ningwu coalfield, China. Chin. J. Geochem. 2015, 34, 391-400. [CrossRef]

63. Wang, W.; Qin, Y.; Song, D.; Sang, S.; Jiang, B.; Zhu, Y.; Fu, X. Element geochemistry and cleaning potential of the No. 11 coal seam from Antaibao mining district. Sci. China Ser. D Earth Sci. 2005, 48, 2142-2154. [CrossRef]

64. Lin, M.; Tian, L. Petrographic characteristics and depositional environment of the No. 9 Coal (Pennsylvanian) from the Anjialing Mine, Ningwu Coalfield, China. Energy Explor. Exploit. 2011, 29, 197-204. [CrossRef]

65. Zhuang, X.; Zeng, R.; Xu, W. Trace elements in 9 coal from Antaibao open pit mine, Pingshuo, Shanxi Province. Earth Sci. J. China Univ. Geosci. 1998, 23, 583-588, (In Chinese with English abstract).

66. Standardization Administration of the People's Republic of China. Sampling of Coal in Seam; Chinese National Standard GB 482-1985; Standardization Administration of the People's Republic of China: Beijing, China, 1985. (In Chinese)

67. ASTM International. Standard Test. Method for Ash in the Analysis Sample of Coal and Coke; ASTM D3174-11; ASTM International: West Conshohocken, PA, USA, 2011.

68. ASTM International. Standard Test. Method for Moisture in the Analysis Sample of Coal and Coke; ASTM D3173-11; ASTM International: West Conshohocken, PA, USA, 2011.

69. ASTM International. Standard Test. Method for Volatile Matter in the Analysis Sample of Coal and Coke; ASTM D3175-11; ASTM International: West Conshohocken, PA, USA, 2011.

70. ASTM International. Standard Test. Method for Total Sulfur in the Analysis Sample of Coal and Coke; ASTM D3177-02; ASTM International: West Conshohocken, PA, USA, 2002.

71. ASTM International. Standard Test. Method for Gross Calorific Value of Coal and Coke; ASTM D5865-13; ASTM International: West Conshohocken, PA, USA, 2013.

72. ASTM International. Standard Test. Method for Microscopical Determination of the Vitrinite Reflectance of Coal; ASTM D2798-11a; ASTM International: West Conshohocken, PA, USA, 2011.

73. Yang, Y.; Zhao, Q. Analysis of aromatic hydrocarbon in medium-to high-sulfur coals from Fenxi, Shanxi Province. World J. Eng. 2018, 15, 786-791. [CrossRef]

74. Standardization Administration of the People's Republic of China. Classification for Quality of Coal_Part. 1: Ash; Chinese National Standard GB/T 15224.1-2018; Standardization Administration of the People's Republic of China: Beijing, China, 2018. (In Chinese)

75. Standardization Administration of the People's Republic of China. Classification for Quality of Coal—Part. 2: Sulfur Content; Chinese National Standard GB/T 15224.2-2010; Standardization Administration of the People's Republic of China: Beijing, China, 2010. (In Chinese)

76. ASTM International. Standard Classification of Coals by Rank; ASTM D388-12; ASTM International: West Conshohocken, PA, USA, 2012.

77. Dai, S.; Ren, D.; Chou, C.; Finkelman, R.B.; Seredin, V.V.; Zhou, Y. Geochemistry of trace elements in Chinese coals: A review of abundances, genetic types, impacts on human health, and industrial utilization. Int. J. Coal Geol. 2012, 94, 3-21. [CrossRef]

78. Liu, Z.; Wei, Y.; Ning, S.; Jia, X.; Qin, R.; Cao, D. The differences of element geochemical characteristics of the main coal seams in the Ningdong coalfield, Ordos Basin. J. Geochem. Explor. 2019, 202, 77-91. [CrossRef] 
79. Dai, S.; Seredin, V.V.; Ward, C.R.; Hower, J.C.; Xing, Y.; Zhang, W.; Song, W.; Wang, P. Enrichment of U-Se-Mo-Re-V in coals preserved within marine carbonate successions: Geochemical and mineralogical data from the Late Permian Guiding Coalfield, Guizhou, China. Miner. Deposita 2015, 50, 159-186. [CrossRef]

80. Ketris, M.P.; Yudovich, Y.E. Estimations of Clarkes for carbonaceous biolithes: World average for trace element contents in black shales and coals. Int. J. Coal Geol. 2009, 78, 135-148. [CrossRef]

81. Academy of Coal Sciences; Ministry of Coal Industry. Sedimentary Environment of the Coal-Bearing Strata in Pinglu-Shuoxian Mining Area, China; Shaanxi People's Education Press: Xi'an, China, 1978; ISBN 1738719. (In Chinese with English abstract).

82. Rollinson, H.R. Using Geochemical Data: Evaluation, Presentation, Interpretation; Longman Scientific Technical Press: London, UK, 1993; ISBN 9780582067011.

83. Taylor, S.R.; McLennan, S.M. The geochemical evolution of the Continental Crust. Rev. Geophys. 1995, 33, 241-265. [CrossRef]

84. Floyd, P.A.; Leveridge, B.E. Tectonic environment of the Devonian Gramscatho basin, south Cornwall: Framework mode and geochemical evidence from turbiditic sandstones. J. Geol. Soc. 1987, 144, 531-542. [CrossRef]

85. Condie, K.C. Plate Tectonics and Crustal Evolution, 4th ed.; Pergamon Press: New York, NY, USA, 1989; ISBN 978-0-7506-3386-4.

86. Song, K.; Lu, J.; Du, J.; Wang, H. Source direction analysis and delta depositional systems of Yanchang Formation of the Upper Triassic in the central Ordos Basin. J. Palaeogeogr. 2002, 4, 59-66, (In Chinese with English abstract).

87. Liu, Y.; Cao, L. Introduction of Elemental Geochemistry; Geological Publishing House: Beijing, China, 1984 ; ISBN 7116000569. (In Chinese)

88. Tribovillard, N.; Algeo, T.J.; Lyons, T.; Riboulleau, A. Trace metals as paleoredox and paleoproductivity proxies: An update. Chem. Geol. 2006, 232, 12-32. [CrossRef]

89. Gu, X.; Liu, J.; Zheng, M.; Tang, J.; Qi, L. Provenance and tectonic setting of the Proterozoic turbidites in Hunan, South China: Geochemical evidence. J. Sediment. Res. 2002, 72, 393-407. [CrossRef]

90. Cullers, R.L. The controls on the major and trace element evolution of shales, siltstones and sandstones of Ordovician to Tertiaty Age in Wet Mountain region, Colorado, USA. Chem. Geol. 1995, 123, 107-131. [CrossRef]

91. Dong, A.; Zhang, S.; Zhong, Z.; Liu, X.; Liu, S. The palaeoclimate and metallogenic environment research during sedimentary bauxite layer in Xing County District in northwest of Shanxi Province. J. Hebei Geo-Univ. 2017, 40, 1-6, (In Chinese with English abstract). [CrossRef]

92. Zhang, S.; Zhang, W.; Zhong, Z.; Sun, J.; Sun, K.; Cao, Y. REE geochemical characteristics and geological significance of bauxite from Xing County, Shanxi Province. J. Chin. Soc. Rare Earths 2018, 36, 338-349, (In Chinese with English abstract). [CrossRef]

93. Laukas, T.C. Origin of bauxite at Eufaula, Alabama, USA. Clay Miner. 1983, 18, 127-138. [CrossRef]

94. Wignall, P.B.; Twitchett, R.J. Oceanic anoxia and the end Permian mass extinction. Science 1996, 272, 1155-1158. [CrossRef]

95. Jones, B.; Manning, D.A.C. Comparison of geochemical indices used for the interpretation of palaeoredox conditions in ancient mudstones. Chem. Geol. 1994, 111, 111-119. [CrossRef]

96. Rimmer, S.M. Geochemical paleoredox indicators in Devonian-Mississippian black shales, Central Appalachian Basin (USA). Chem. Geol. 2004, 206, 373-391. [CrossRef]

97. Lee, J.H.; Byrne, R.H. Examination of comparative rare earth element complexation behavior using linear free-energy relationships. Geochim. Cosmochim. Acta 1992, 56, 1127-1137. [CrossRef]

98. Tissot, B.T.; Welte, D.H. Petroleum Formation and Occurrence. Springer: Berlin/Heidelberg, Germany, 1978; ISBN 3540132813. (Berlin).

99. Mei, B.; Liu, X. The distribution of isoprenoid alkanes in China's crude oil and its relation with the geologic environment. Oil Gas. Geol. 1980, 1, 99-115, (In Chinese with English abstract).

100. Peters, K.E.; Moldowan, J.M. The Biomarker Guide: Interpreting Molecular Fossils in Petroleum and Ancient Sediments; Prentice Hall: Englewood Cliffs, NJ, USA, 1993; ISBN 0-13-086752-7.

101. Peters, K.E.; Fraser, T.H.; Amris, W.; Rustanto, B.; Hermanto, E. Geochemistry of crude oils from eastern Indonesia. AAPG Bull. 1999, 83, 1927-1942. [CrossRef]

102. Meng, Q.; Zhang, S.; Cui, M.; Li, Z.; Wang, Y.; Fan, P. Distribution features of aromatics in Lacustrine low-mature crude oils from different environments. Acta Sedimentol. Sin. 1999, 17, 112-119, (In Chinese with English abstract). [CrossRef]

103. Radke, M.; Rullkötter, J.; Vriend, S.P. Distribution of naphthalenes in crude oils from the Java Sea: Source and maturation effects. Geochim. Cosmochim. Acta 1994, 58, 3675-3689. [CrossRef]

104. Hites, R.A.; Laflamme, R.E.; Windsor, J.G., Jr.; Farington, J.W.; Deuser, W.G. Polycyclic aromatic hydrocarbons in an anoxic sediment core from the Pettaquamscutt River (Rhode Island, U.S.A.). Geochim. Cosmochim. Acta 1980, 44, 873-878. [CrossRef]

105. Venkatesan, M.I. Occurrence and possible sources of perylene in marine sediments-A review. Mar. Chem. 1988, 25, 1-27. [CrossRef]

106. Grice, K.; Lu, H.; Atahan, P.; Asif, M.; Hallmann, C.; Greenwood, P.; Maslen, E.; Tulipani, S.; Williford, K.H.; Dodson, J. New insights into the origin of perylene in geological samples. Geochim. Cosmochim. Acta 2009, 73, 6531-6543. [CrossRef]

107. Marynowski, L.; Smolarek, J.; Bechtel, A.; Philippe, M.; Kurkiewicz, S.; Simoneit, B.R.T. Perylene as an indicator of conifer fossil wood degradation by wood-degrading fungi. Org. Geochem. 2013, 59, 143-151. [CrossRef]

108. Denis, E.H.; Toney, J.L.; Tarozo, R.; Anderson, R.S.; Roach, L.D.; Huang, Y. Polycyclic aromatic hydrocarbons (PAHs) in lake sediments record historic fire events: Validation using HPLC-fluorescence detection. Org. Geochem. 2012, 45, 7-17. [CrossRef]

109. Zdravkov, A.; Bechtel, A.; Sachsenhofer, R.F.; Kortenski, J. Palaeoenvironmental implications of coal formation in Dobrudzha Basin, Bulgaria: Insights from organic petrological and geochemical properties. Int. J. Coal Geol. 2013, 180, 1-17. [CrossRef] 
110. Silliman, J.E.; Meyers, P.A.; Eadie, B.J. Perylene: An indicator of alteration processes or precursor materials? Org. Geochem. 1998, 29, 1737-1744. [CrossRef]

111. Scott, A.C.; Jones, T.P. The nature and influence of fire in Carboniferous ecosystems. Palaeogeogr. Palaeoclimatol. Palaeoecol. 1994, 106, 91-112. [CrossRef]

112. Han, D. Coal Petrology of China; Publishing House of China University of Mining and Technology: Xuzhou, China, 1996; ISBN 9787810404488. (In Chinese with English abstract).

113. Kennedy, K.L.; Gibling, M.R.; Eble, C.F.; Gastaldo, R.A.; Gensel, P.G.; Werner-Zwanziger, U.; Wilson, R.A. Lower Devonian coaly shales of northern New Brunswick, Canada: Plant accumulations in the early stages of terrestrial colonization. J. Sediment. Res. 2014, 83, 1202. [CrossRef]

114. Deng, H.; Qian, K. Sedimentary Geochemistry and Environment; Gansu Science and Technology Press: Lanzhou, China, 1993; ISBN 7-5424-0471-7/P.18. (In Chinese)

115. Hu, X.; Wang, C.; Li, X.; Fan, S.; Peng, P. Cenomanian-Turonian anoxic event in southern Tibet: A study of organic geochemistry. Chin. J. Geochem. 2000, 4, 289-295. [CrossRef]

116. Bao, J.; Chen, X.; Zhu, C. Novel $C_{15}$ sequiterpanes and their origin in different crude oils from the Pearl River Mouth Basin of China. Sci. China Earth Sci. 2016, 59, 1622-1632. [CrossRef]

117. Meng, Q.; Fang, X.; Xu, Y.; Shen, P. Biomarkers and geochemical significance of Carboniferous source rocks and coals from Qaidam Basin. Acta Sedimentol. Sin. 2004, 22, 729-736, (In Chinese with English abstract). [CrossRef]

118. Adams, J.A.S.; Weaver, C.E. Thorium-to-uranium ratios as indicators of sedimentary processes: Example of concept of geochemical facies. AAPG Bull. 1958, 42, 387-430. [CrossRef]

119. Wood, S.A.; Samson, I.M. The aqueous geochemistry of gallium, germanium, indium and scandium. Ore Geol. Rev. 2006, 28, 57-102. [CrossRef]

120. Gautam, S.; Prasad, N.; Patra, A.K.; Prusty, B.K.; Singh, P.; Pipal, A.S.; Saini, R. Characterization of $\mathrm{PM}_{2.5}$ generated from opencast coal mining operations: A case study of Sonepur Bazari Opencast Project of India. Environ. Technol. Innov. 2016, 6, 1-10. [CrossRef]

121. Kurth, L.; Koller, A.; Engle, M.; Geboy, N.; Hendryx, M.S.; Orem, W.H.; McCawley, M.; Crosby, L.; Tatu, C.; Varonka, M.; et al. Atmospheric particulate matter in proximity to mountaintop coal mines: Sources and potential environmental and human health impacts. Environ. Geochem. Health 2015, 37, 529-544. [CrossRef]

122. Pope, C.A., III; Burnett, R.T.; Thun, M.J.; Calle, E.E.; Krewski, D.; Ito, K.; Thurston, G.D. Lung cancer, cardiopulmonar mortality, and long-term exposure to fine particulate air pollution. J. Am. Med. Assoc. 2002, 278, 1132-1141. [CrossRef]

123. World Health Organization (WHO). Health Aspects of Air Pollution with Particulate Matter, Ozone and Nitrogen Dioxide, Report on a WHO Working Group. 2003. Available online: https:/ / www.euro.who.int/en/health-topics/environment-and-health/airquality / publications / pre2009/health-aspects-of-air-pollution-with-particulate-matter,-ozone-and-nitrogen-dioxide (accessed on 10 October 2020).

124. International Agency for Research on Cancer (IARC). Outdoor Air Pollution: A Leading Environmental Cause of Cancer Deaths. 2013. Available online: http://connection.ebscohost.com/c/articles/92949438/iarc-outdoor-air-pollution-leadingenvironmental-cause-cancer-deaths (accessed on 10 October 2020).

125. World Health Organization (WHO). Ambient Air Pollution: A Global Assessment of Exposure and Burden of Disease. 2016. Available online: https://www.who.int/phe/publications/air-pollution-global-assessment/en/ (accessed on 10 October 2020).

126. Humbal, C.; Gautam, S.; Trivedi, U. A review on recent progress in observations, and health effects of bioaerosols. Environ. Int. 2018, 118, 189-193. [CrossRef] [PubMed]

127. Roy, D.; Singh, G.; Seo, Y. Carcinogenic and non-carcinogenic risks from $\mathrm{PM}_{10}$ - and $\mathrm{PM}_{2.5}$-Bound metals in a critically polluted coal mining area. Atmos. Pollut. Res. 2019, 10, 1964-1975. [CrossRef]

128. Huang, X.; Li, W.; Attfield, M.D.; Nadas, A.; Frenkel, K.; Finkelman, R.B. Mapping and prediction of coal workers' pneumoconiosis with bioavailable iron content in bituminous coals. Environ. Health Perspect. 2004, 113, 964-968. [CrossRef]

129. Hendryx, M. Mortality from heart, respiratory, and kidney disease in coal mining areas of Appalachia. Int. Arch. Occup. Environ. Health 2009, 82, 243-249. [CrossRef] [PubMed]

130. Hendryx, M. Poverty and mortality disparities in central Appalachia: Mountaintop mining and environmental justice. J. Health Disparities Res. Pract. 2011, 4, 44-53.

131. Cardoso, A. Behind the life cycle of coal: Socio-environmental liabilities of coal mining in Cesar, Colombia. Ecol. Econ. 2015, 120, 71-82. [CrossRef]

132. Jayaranjan, M.L.D.; Hullebusch, E.D.; Annachhatre, A.P. Reuse options for coal fired power plant bottom ash and fly ash. Rev. Environ. Sci. Biol. Technol. 2014, 13, 467-486. [CrossRef]

133. Seames, W.S. An initial study of the fine fragmentation fly ash particle mode generated during pulverized coal combustion. Fuel Process. Technol. 2003, 81, 109-125. [CrossRef]

134. Zhao, S.; Duan, Y.; Lu, J.; Liu, S.; Pudasainee, D.; Gupta, R.; Liu, M.; Lu, J. Enrichment characteristics, thermal stability and volatility of hazardous trace elements in fly ash from a coal-fired power plant. Fuel 2018, 255, 490-498. [CrossRef]

135. Swanson, S.M.; Engle, M.A.; Ruppert, L.F.; Affolter, R.H.; Jones, K.B. Partitioning of selected trace elements in coal combustion products from two coal-burning power plants in the United States. Int. J. Coal Geol. 2013, 113, 116-126. [CrossRef] 
136. Das, R.; Khezri, B.; Srivastava, B.; Datta, S.; Sikdar, P.K.; Webster, R.D.; Wang, X. Trace element composition of $\mathrm{PM}_{2.5}$ and $\mathrm{PM}_{10}$ from Kolkata-A heavily polluted Indian metropolis. Atmos. Pollut. Res. 2015, 6, 742-750. [CrossRef]

137. Zhao, S.; Duan, Y.; Tan, H.; Liu, M.; Wang, X.; Wu, L.; Wang, C.; Lv, J.; Yao, T.; She, M.; et al. Migration and emission characteristics of trace elements in a $660 \mathrm{MW}$ coal-fired power plant of China. Energy Fuels 2016, 30, 45-48. [CrossRef]

138. Liu, S.; Zhang, Z.; Wang, Y.; Hu, Y.; Liu, W.; Chen, C.; Mei, Y.; He, S. PM 2.5 emission characteristics of coal-fired power plants in Beijing-Tianjin-Hebei region, China. Atmos. Pollut. Res. 2019, 10, 954-959. [CrossRef]

139. George, A.; Shen, B.; Kang, D.; Yang, J.; Luo, J. Emission control strategies of hazardous trace elements from coal-fired power plants in China. J. Environ. Sci. 2020, 93, 66-90. [CrossRef] [PubMed]

140. Dwivedi, S.; Saquib, Q.; Al-Khedhairy, A.A.; Ali, A.Y.; Musarrat, J. Characterization of coal fly ash nanoparticles and induced DNA damage in human peripheral blood mononuclear cells. Sci. Total Environ. 2012, 437, 331-338. [CrossRef] [PubMed]

141. Gasparotto, J.; Martinello, K.D.B. Coal as an energy source and its impacts on human health. Energy Geosci. 2020, in press. [CrossRef]

142. Aneja, V.P.; Isherwood, A.; Morgan, P. Characterization of particulate matter $\left(\mathrm{PM}_{10}\right)$ related to surface coal mining operations in Appalachia. Atmos. Environ. 2012, 54, 496-501. [CrossRef]

143. Rauner, S.; Bauer, N.; Dirnaichner, A.; Dingenen, R.V.; Mutel, C.; Luderer, G. Coal-exit health and environmental damage reductions outweigh economic impacts. Nat. Clim. Chang. 2020, 10, 308-312. [CrossRef]

144. Semara, C.; Argyropoulos, G.; Grigoratos, T.; Kouras, A.; Manoli, E.; Andreadou, S.; Pavloudakis, F.; Sahanidis, C. Chemical characterization and receptor modeling of $\mathrm{PM}_{10}$ in the surroundings of the opencast lignite mines of Western Macedonia, Greece. Environ. Sci. Pollut. Res. 2018, 25, 12206-12221. [CrossRef]

145. Homma, T.; Ueno, T.; Sekizawa, K.; Tanaka, A.; Hirata, M. Interstitial pneumonia developed in a worker dealing with particles containing indium-tin oxide. J. Occup. Health 2003, 45, 137-139. [CrossRef]

146. Font, O.; Querol, X.; López-Soler, A.; Chimenos, J.M.; Fernández, A.I.; Burgos, S.; Peña, F.G. Ge extraction from gasification fly ash. Fuel 2005, 84, 1384-1392. [CrossRef]

147. Yao, Z.; Ji, X.; Sarker, P.K.; Tang, J.; Ge, L.; Xia, M.; Xi, Y. A comprehensive review on the applications of coal fly ash. Earth Sci. Rev. 2015, 141, 121-150. [CrossRef]

148. Valeev, D.; Kunilova, I.; Alpatov, A.; Mikhailova, A.; Goldberg, M.; Kondratiev, A. Complex utilisation of ekibastuz brown coal fly ash: Iron \& carbon separation and aluminum extraction. J. Clean. Product. 2019, 218, 192-201. [CrossRef]

149. Syu, C.H.; Chen, P.W.; Huang, C.C.; Lee, D.Y. Accumulation of gallium (Ga) and indium (In) in rice grains in Ga- and Incontaminated paddy soils. Environ. Pollut. 2020, 261, 114189. [CrossRef] [PubMed]

150. Omae, K.; Nakano, M.; Tanaka, A.; Hirata, M.; Hamaguchi, T.; Chonan, T. Indium lung-case reports and epidemiology. Int. Arch. Occup. Environ. Health 2011, 84, 471-477. [CrossRef]

151. National Health Commission of the People's Republic of China. Occupational Exposure Limits for Hazardous Agents in The WorkplacePart 1: Chemical Hazardous Agents; National Occupational Health Standard GBZ 2.1-2019; National Health Commission of the People's Republic of China: Beijing, China, 2019. (In Chinese) 